\title{
The Xiaoyangqiao section, Dayangcha, North China: the new global Auxiliary Boundary Stratotype Section and Point (ASSP) for the base of the Ordovician System
}

\author{
${ }^{1}$ Wuhan Center of China Geological Survey (Wuhan Institute of Geology \& Mineral Resources), Wuhan, China \\ ${ }^{2}$ Natural History Museum of Denmark, University of Copenhagen, Copenhagen, Denmark; *Corresponding author, E-mail: svends@snm.ku.dk \\ ${ }^{3}$ Institute of Geology, Free University of Berlin, Germany \\ ${ }^{4}$ Dipartimento di Scienze della Terra, Via S. Maria 53, I-56126 Pisa, Italy \\ ${ }^{5}$ State Key Laboratory of Palaeobiology and Stratigraphy, Nanjing Institute of Geology and Palaeontology, Chinese Academy of Sciences, \\ 39 East Beijing Road, Nanjing, 210008, China \\ ${ }^{6}$ AO 'Geologorazvedka'. Fayansovaya Stra 20, building 2, lti. A, St-Petersburg, 192019, Russia
}

(Received: February 4, 2020; Revised accepted: November 6, 2020)

https://doi.org/10.18814/epiiugs/2020/020091

In 2019 the Sub-Commission on the Ordovician System approved the Xiaoyangqiao section, North China as a new ASSP section for the base of the Ordovician System. The sedimentary succession of the section is exposed in a natural outcrop near the Dayangcha Village at a position of $42^{\circ} 3^{\prime} 24^{\prime \prime} N, 126^{\circ} 42^{\prime} 21^{\prime \prime} E$. It has a well-preserved, abundant and diverse fossil record across the boundary with key markers (conodonts and graptolites), which provide improved intercontinental correlation of the CambrianOrdovician boundary. The appearance of the first planktonic graptolites is immediately below the base of the Cordylodus lindstromi Conodont Zone. Other fossils, including acritarchs, brachiopods and trilobites are also present in the Xiaoyangqiao ASSP section. Non-biotic secondary global markers near the base of the Ordovician System include a positive carbon isotopic excursion with the maximum peak (named HSS) below the boundary, a prominent unnamed negative peak immediately below the boundary and a prominent carbon isotope excursion with positive peaks above the boundary. The latter excursion is associated with the appearance of the planktonic graptolites in the Ordovician. The strength of the Xiaoyangqiao ASSP section is the correlation between the conodonts and graptolites, correspondence of sea-level lowstands, and the matches of geochemical parameters.

\section{Introduction}

The fossiliferous Cambrian-Ordovician deposits in the Dayangcha area, North China, are well-known from papers in Chen (1986, with references), Chen et al. (1988), and Wang et al. (2019), who reported on the occurrence of graptolites, trilobites, acritarchs and conodonts sampled at many horizons within the succession.

The late Cambrian-earliest Ordovician succession, informally assigned to the Dayangcha beds (Erdtmann, 1986; Wang et al., 2019), has been the subject of extensive studies over the past four years by a joint team of researchers from China, Denmark, Germany, Italy and Russia. The team revisited the Xiaoyangqiao section, Dayangcha, China to collect samples for stratigraphic and geochemical studies. This work has resulted in the development of a new lithostratigraphic subdivision of the area and high-resolution integrated bio-, sequence-, chemo- and magneto-stratigraphic subdivisions (Wang et al., 2019). These efforts, together with the integration of the last 30 years of research on the Xiaoyangqiao section have successfully been used for correlation with and detailed comparison to the Green Point GSSP section in Western Newfoundland, Canada. The results have demonstrated that the Xiaoyangqiao section provides a strong foundation for the identification of the global Cambrian-Ordovician boundary level and its international correlation (Wang et al., 2019), which is described herein.

\section{Brief Historical Background}

Two International Working Groups (COWGB I, II) were established to formally define and select the GSSP for the Cambrian-Ordovician boundary. The working groups organized several meetings and studied several sections in detail over more than 20 years. The chairperson of the second Cambrian-Ordovician boundary working group submitted in 1999 a written proposal to the International Commission on Stratigraphy (ICS). In this proposal the selected GSSP of the Cambrian-Ordovician boundary was defined at the first appearance of the 
conodont species 'Iapetognathus' fluctivagus Nicoll, Miller, Nowlan, Repetski and Ethington, 1999 and the horizon was placed within unit 23 at the Green Point GSSP section, Western Newfoundland, Canada (see below). The International Commission on Stratigraphy approved the proposal in 1999 and the International Union of Geological Sciences (IUCS) ratified it in 2000.

Cooper et al. (2001) did not provide any auxiliary section in their formal presentation in which the chosen level could be studied in other facies with different faunal assemblages and in different palaeobiogeographical settings, to enhance precise global correlation. Miller et al. (2015) promoted the Lawson Cove section, Ibex Area, Utah, USA, as auxiliary section using the FAD of 'Iapetognathus' fluctivagus as a marker for the base of the Ordovician System. This proposal was shortly afterwards approved by the Subcommission on Ordovician Stratigraphy (Miller, 2017, 2020). The Lawson Cove ASSP section is a succession characterized by shallow-water carbonates with shallowwater shelly faunas and without graptolites.

Terfelt et al. (2012) revised the conodont fauna from the Green Point GSSP section. They re-assigned the taxon appearing at the Green Point GSSP horizon, and previously named Iapetognathus fluctivagus (Nicoll et al., 1999; Miller et al., 2014), to Iapetognathus preaengensis Landing in Forty et al., 1982 (cf., Barnes 1988; Wang et al., 2019). Terfelt et al. (2012) also recorded Iapetognathus fluctivagus at a stratigraphic level above the first appearance of planktonic graptolites in the Green Point GSSP section.

The selection of the Lawson Cove section as ASSP section did not solve the long-existing correlation problems across facies. Due to this discrepancy, and in order to solve several problems in precise intercontinental correlation, Wang et al. (2019) recommended the Xiaoyangqiao section, North China, as a new global ASSP for the base of the Ordovician System. The Subcommission on Ordovician Stratigraphy approved this proposal in 2019.

\section{The Base of the Ordovician System: Auxiliary Sections and Correlation}

\section{Auxiliary Sections}

The auxiliary section fulfills all - or almost all - of the requirements to characterize a GSSP (Remane et al., 1996). Among the recommendations for the base of the Ordovician System are: (1) the chronostratigraphic boundary should preferably be defined in a continuous rock sequence without any appreciable gap; (2) the apparent first occurrence of a carefully selected fossil taxon should be taken for positioning the 'golden spike' in that succession, and (3) the chosen level should be placed below the first appearance of planktonic graptolites.

The Lawson Cove ASSP Section, USA that is from the same palaeogeographical plate (i.e., Laurentia) as the Green Point GSSP section in western Newfoundland, Canada, is useful for correlation of shallow-water carbonate platform deposits on the North American continent and elsewhere. The Xiaoyangqiao ASSP section described below is located in a different part of the palaeo-globe than the Green Point GSSP section and far from North America, but it provides precise intercontinental correlation across different palaeogeographical regions (Terfelt et al., 2012; Wang et al., 2019).

\section{Correlation and Correlation Problems}

The recognition of a chronostratigraphic boundary in other sections is a problem of correlation. The correlation may be easier if the fossil species, originally selected for defining the boundary, also occurs elsewhere in as many sections as possible, if other fossil taxa occurring in the type section are widely distributed as well, and if other evidence is available (Hedberg, 1976, p. 86).

The correlation problem of the Cambrian-Ordovician boundary includes different taxonomic interpretation of the taxa and longstanding difficulty correlating the shallow-water deposits (i.e., of North America and similar deposits) to the deep-water slope deposits of the Green Point GSSP section. The Lawson Cove succession is without graptolites, and all attempts to directly correlate the Lawson Cove ASSP section precisely to the deep-water Green Point GSSP section have failed (Fortey et al., 1982; Erdtmann, 1986, 1988; Cooper et al., 1998; Cooper, 1999; Miller and Flokstra, 1999; Dubinina, 2000; Cooper et al., 2001; Miller et al., 2003, 2015; Terfelt et al., 2012; Miller, 2020). By using the succession at the Xiaoyangqiao ASSP section, this correlation has now been executed successfully (Wang et al., 2019).

\section{The Xiaoyangqiao ASSP Section, Jilin Province, North China}

The Xiaoyangqiao ASSP section in North China (Figs. 1, 2) is described here. The Cambrian-Ordovician boundary interval is well displayed in the Xiaoyangqiao ASSP section with continuous, expanded sedimentation and containing an abundance of significant marine fossil groups including acritarchs, brachiopods, conodonts, graptolites and trilobites. In addition, the section is classical, very well known, and easily accessible, has been exhaustively studied (Chen, 1986; Chen et al., 1983, 1988); Wang et al., 2019, and reference therein) and allows for a detailed global correlation.

\section{Geographic Location}

The Xiaoyangqiao ASSP section lies about $2.5 \mathrm{~km}$ northeast of the town of Dayangcha, Baishan (formerly Hunjiang), Jilin Province, North China (Fig. 1; Chen, 1986; Chen et al., 1988; Wang et al., 2017, 2019). Geographical coordinates of the measured section are $42^{\circ} 3^{\prime} 24^{\prime \prime} \mathrm{N}$, $12642^{\prime} 21^{\prime \prime} \mathrm{E}$, at an elevation of $642 \mathrm{~m}$. It lies along the northwest side of a small rivulet - a tributary of the Hunjiang (river) - and is a cliff exposure within a monocline dipping evenly degrees missing.

The Sanduiliaochang quarry, ca. six km northeastwards of the Xiaoyangqiao section (Fig. 1B), is an additional exposure along strike of the succession. The stratigraphic succession is continuous downwards, to the south, along the road to Dayangcha and upwards to the west. The Xiaoyangqiao ASSP section and the westerly facing section with exposures of the Yeli Formation, situated just to the south of the Xiaoyangqiao ASSP section, are traditionally named the Xiaoyangqiao Composite section (XCS) (Chen, 1986; Zhang, 1986; Fig. 1). The sections, i.e., the lower section (XLS) and the Xiaoyangqiao Composite section (XCS), represent an important and complete succession from the upper Furongian into the lower Tremadocian (Lower Ordovician) (Chen, 1986). 


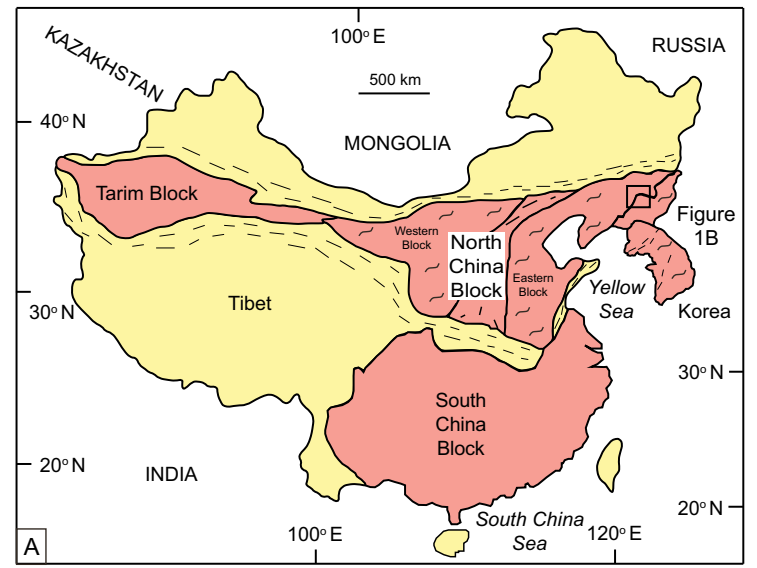

Legend

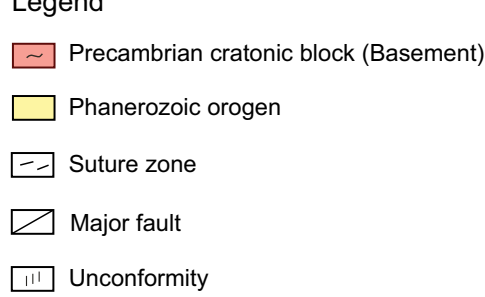

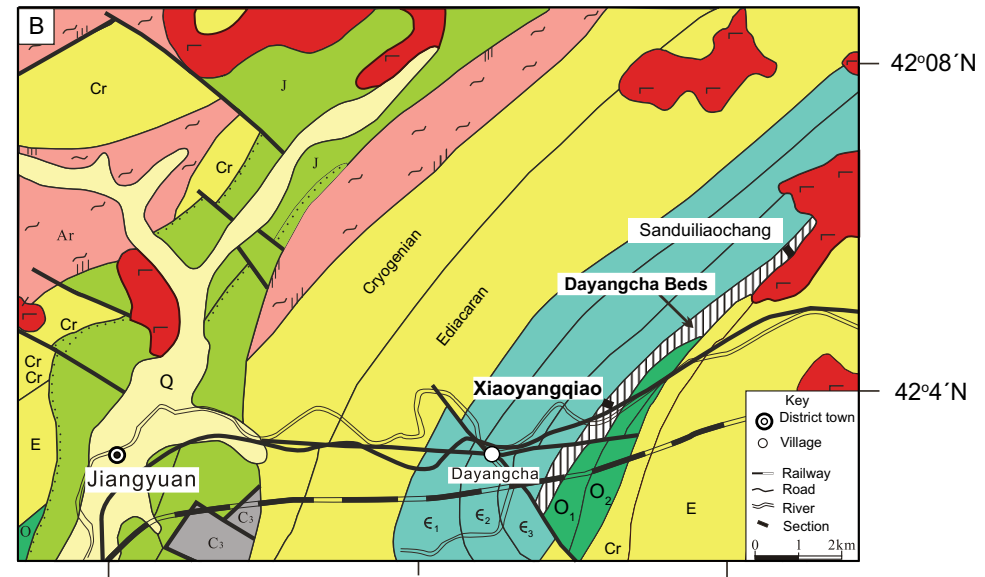

$126^{\circ} 35^{\prime} \mathrm{E}$ $126^{\circ} 45^{\prime} \mathrm{E}$
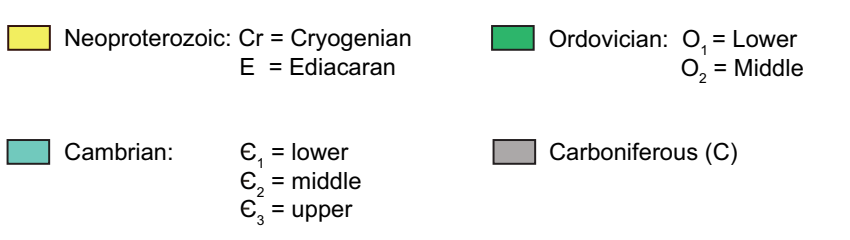

Pleistocene (Q)

Intrusive rocks

Mesozoic: J = Jurassic

Figure 1. (A) Main China plates (Tarim, North China and South China. (B) Geological and location map of the study area (modified from Wang et al., 2019, fig. 1).

\section{Access}

The Xiaoyangqiao ASSP section is reached by car in approximately 40 min from Baishan City, ca. 10 min from Jiangyuan County, and 5 min from the town of Dayangcha (Fig. 1); alternatively, the train from Baishan takes about 30 min.

\section{Previous Work}

The lithology, fossil record and stratigraphy of the upper Cambrian (Stage 10, Furongian Series) and Lower Ordovician (Tremadocian) succession of the Xiaoyangqiao ASSP section has been studied by Kuo et al. (1982), Zhou et al. (1984), Chen et al. (1983, 1985, 1988, 1995), Chen (1986) and Zhang et al. (1996). The biota comprises acritarchs, conodonts, brachiopods, graptolites and trilobites in great variety and abundance. Erdtmann (1986), Lin (1985, 1986), Wang and Erdtmann (1987), Zhang and Erdtmann (2004), Maletz et al. (2017) and Wang et al. (2019) studied graptolites from the section and the region. Chen et al. (1985) followed by Chen and Gong (1986) and Wang et al. (2019) documented the conodont succession with additional information provided by Nowlan and Nicoll (1995) and Nicoll et al. (1999). Yin (1985, 1986) described the acritarch assemblages from the section. Chen et al. (1986) described the distribution of rare earth elements in the succession of the Dayangcha beds and Yang et al. (1986) assigned a latest Cambrian age, 500.7 $\pm 7.4 \mathrm{Ma}$, based on the Rb-Sr method (horizon HBA 9B1) for one horizon within the lower part of the section (sample HDA 9B, Cordylodus caboti Zone). Ripperdan et al. (1992, 1993) and Chen et al. (1995), independently, presented similar $\mathrm{d}^{13} \mathrm{C}_{\text {carb }}$-isotope curves from the Xiaoyangqiao ASSP section. Ripperdan and Kirschvink (1992) and Ripperdan et al. (1993) introduced the magne- tostratigraphy of the Cambrian-Ordovician interval and correlated the magnetostratigraphy with the biostratigraphic data. Recently, Wang et al. (2019) revised all previous palaeontological, sedimentological and non-biotic data, added new data and provided a comprehensive review of the Xiaoyangqiao ASSP section.

\section{Geological Setting}

The strata exposed at the Xiaoyangqiao ASSP section are contained within the upper Cambrian and Lower Ordovician sedimentary successions that accumulated on platform to platform margin of the North China Craton. The stable North China Craton (NCC or Sino-Korean Craton, SKC) (Fig. 1A) traditionally comprises most of North China and parts of the Korean Peninsula (Zhu et al., 2012; Zheng et al., 2013; Cho et al., 2017). The Cambrian-Ordovician platform succession is about 500 to $1000 \mathrm{~m}$ thick; it is mainly composed of marine shallowwater deposits with intervals of extensive biostromal microbialites (Lee et al., 2012), some mixed carbonates and siliciclastics, and evaporites (gypsum), oolites and lime breccias.

During the late Cambrian and Early Ordovician the North China plate occupied a tropical position and the sedimentary succession was mainly deposited in an extensive epicontinental sea (Meyerhoff et al., 1991; Meng et al., 1997). The North China plate was tectonically stable during most of the Cambrian, but a hiatus of variable magnitude across the Cambrian-Ordovician boundary is developed at many sites on the North China platform. A prominent hiatus extending from middle to late Floian (Early Ordovician) into the early Darriwilian (Middle Ordovician) interrupted the Ordovician succession in North China (Wang et al., 2016; Zhen et al., 2016). The sedimentation on the North China plate resumed in the Middle Ordovician and persisted into the 
early Late Ordovician. A second extensive hiatus developed and lasted from early Late Ordovician into late Carboniferous times (Wang et al., 1985, 2016; Zhen et al., 2016; Lee et al., 2017).

\section{Description of the Global Xiaoyangqiao ASSP Section}

The Xiaoyangqiao section is exposed over a distance of about a hundred meters along the cliff on the western side of the road and rivulet (Figs 1B; 2). Chen et al. (1985, 1988), Zhang et al. (1996) and Wang et al. $(2017,2019)$ documented the succession at the Xiaoyangqiao ASSP section.
A general view of the outcrop to the east is shown in Fig. 2, and a lithostratigraphic $\log$ in Fig. 3. The succession is predominantly a mixed carbonate-argillaceous sequence with a varying amount of carbonate content. The base is drawn near the beginning of the trail along the rivulet; the zero datum in this account is just below the prominent stromatolite marker in the section (Figs. 2, 3).

The upper Cambrian - Lower Ordovician Dayangcha beds are exposed in the area along strike to either side of the measured section. The additional section at Sanduiliaochang comprises the same facies of the Dayangcha beds and exposes the boundary to the overlying Yeli formation (Fig. 1B). It displays a well-preserved graptolite fauna and well-developed graptolite succession (Maletz et al., 2017; Wang et al., 2017, 2019).
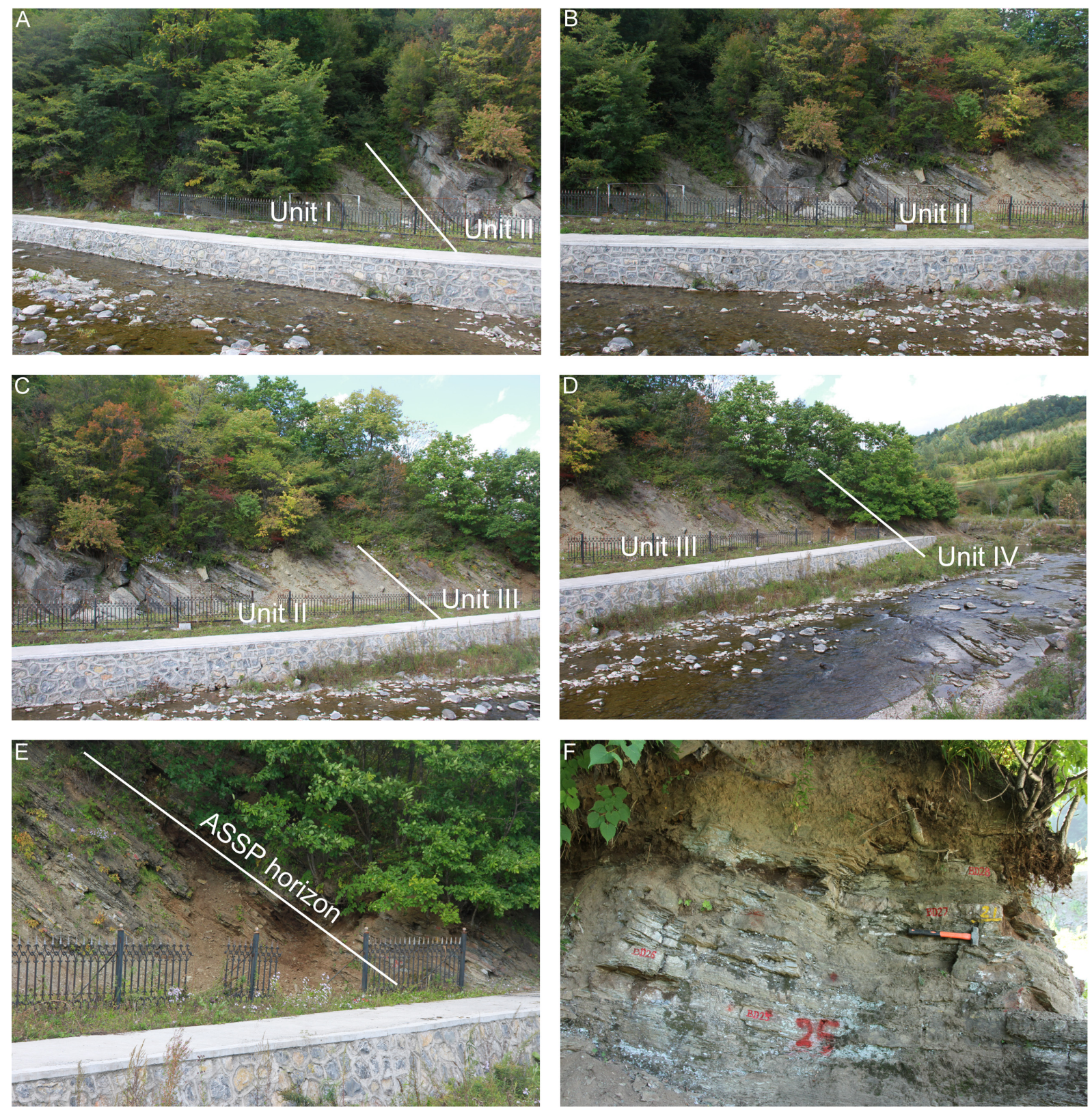

Figure 2. Photos of the Xiaoyangqiao ASSP section. (A) Top of lithological unit I and base of unit II. The white line marks the baseline for the log in Figure 3. (B) Lower part of lithological unit II with the stromatolite horizon (1.6 m thick). (C) Units II and III. (D) Upper part of lithologic unit III and lower part of lithologic unit IV. (E) Upper part of unit III and the approximate position of the ASSP level for the Cambrian-Ordovician boundary (between BD 23 and BD 25). (F) Position of the FAD of the first planktonic graptolite at +20.9 m (at hammer on the photo). 


\section{Lithostratigraphy}

Dayangcha beds (Furongian, upper Cambrian-Tremadocian, Lower Ordovician)

The $40 \mathrm{~m}$-thick interbedded siltstone, shale, limestone, boundstone and stratabound breccia, and overlying the Fengshan Formation (Furongian) are named the Dayangcha beds (cf. Erdtmann, 1986; Wang et al., 2019)
(Fig. 3). The Dayangcha beds are dominated by silty mudstone, calcareous mudstone and shale containing carbonate lenticles in the lower and upper portion. The upper part, containing the graptolite fauna consists of black shale, grey siltstone and horizons with very thin lenticles of limestone.

The marine mixed siliciclastic-carbonates and carbonates of the Dayangcha beds are transitional between shallow-water carbonate platform deposits and deeper-water siliciclastic deposits. The succes-

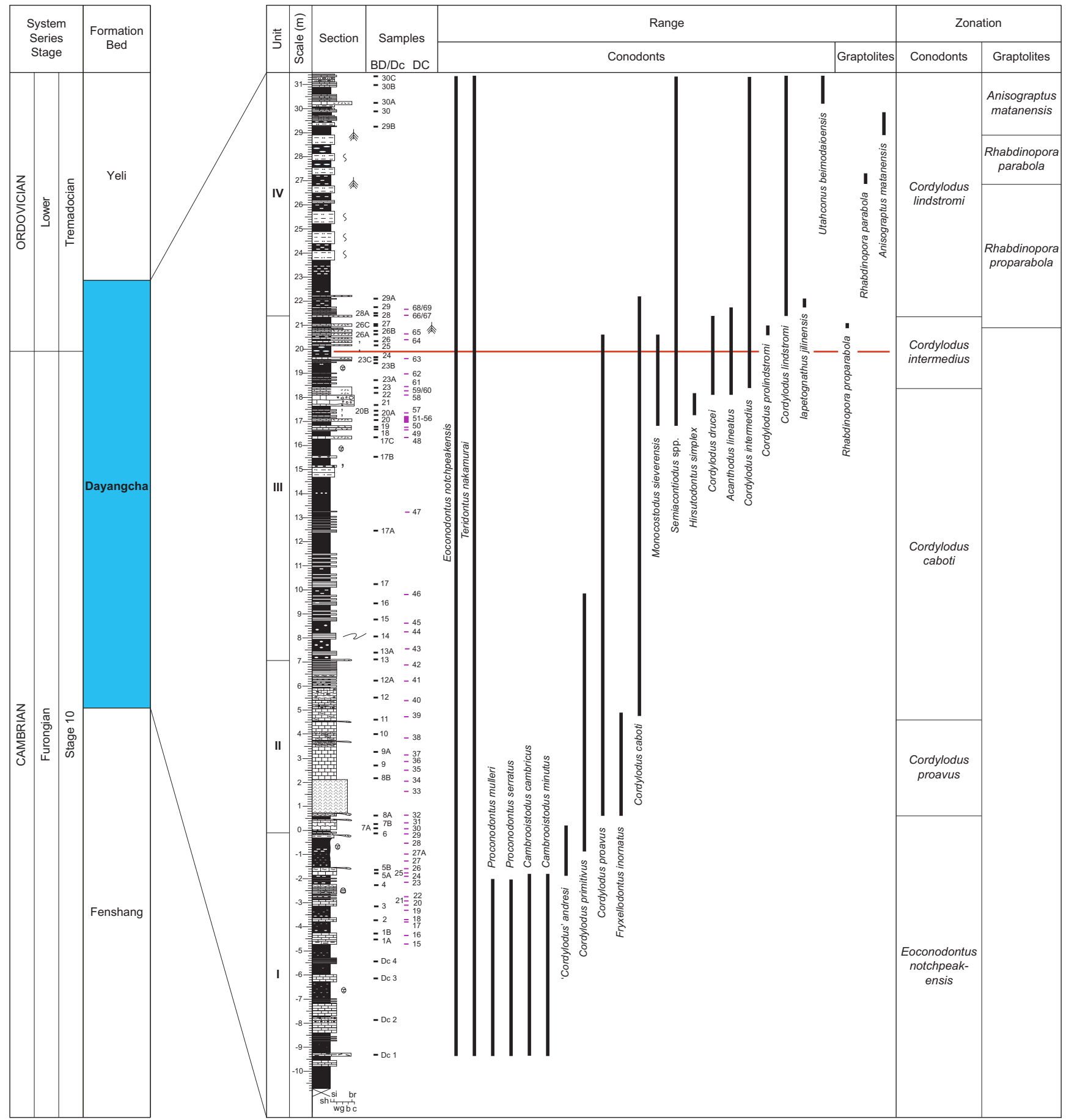

Figure 3. Stratigraphical column of the Cambrian-Ordovician deposits of the Xiaoyangqiao ASSP section, showing lithostratigraphical subdivision, position of sampled fossiliferous horizons, ranges of significant conodont and graptolite species and biozones (modified from Wang et al., 2019, fig. 3). The red line is the interpreted position of the GSSP horizon. (For legend see Fig. 8; abbreviations used for grainsize: sh = shale; si = siltstone; $b r=$ breccia $=; w=$ wackestone; $g=$ grainstone; $b=$ boundstone; $c=$ conglomerate). 
sion represents an upward-deepening and upward shallowing rhythmic sedimentation on the outer platform to the margin of the carbonate platform (Zhang, 1986; Zhang and Chen, 1986; Chen et al., 1988; Zhang et al., 1996; Wang et al., 2019).

There is a series of lithologic units of regional extent (Wang et al., 2019). These are:

- Unit I. - $11.0 \mathrm{~m}$ thick succession of rhythmic bedded shale and limestone, interbedded shale and limestone and shale, and thin layers of carbonate lenticles.

- Unit II. - $7.3 \mathrm{~m}$ of carbonate platform deposits characterized by a strata-bound stromatolite marker horizon, 1.4-1.6 m thick, at the base of the unit (Figs. 2, 3). This is an easily recognizable lithofacies of the shallow to deeper water carbonate platform. It is followed by a sequence composed of shallow to deep-water carbonate deposits.

- Unit III. - Unit III is composed of shale, siltstone interbedded with minor thin argillaceous, commonly nodular, limestone beds. Glauconite becomes common in the upper part of unit III. Input of carbonate conglomerate and imbricated lime-breccia horizons is recorded in the middle of the unit and a series of strata-bound lime-breccia beds defines the top of the unit. Trilobites are the most common allochems in unit III. It is ca. $14.0 \mathrm{~m}$ thick.

- Unit IV. - Unit IV comprises siliciclastic sedimentary rocks, composed of green, light grey to black shale, and grey to lightgrey siltstone and few fine-grained sandstone beds. A few beds of limestone are recorded at the top of the unit. Unit IV yields a prolific graptolite fauna. Unit IV is more than $9.8 \mathrm{~m}$ thick. The upper boundary of unit IV is not exposed in the Xiaoyangqiao ASSP section.

\section{Yeli Formation (lower Tremadocian)}

The overlying Yeli Formation (Grabau, 1922; Zhang, 1962; Wang et al., 1996; Zhang and Erdtmann, 2004; Wang et al., 2019) is composed of carbonate sedimentary rocks with subordinate shale bed (Zhang, 1962; Wang et al., 1996, 2019). The Yeli Formation is exposed in the other small rivulet, extending westward, immediately to the south of the Xiaoyangqiao section, along the road heading to the northeast (Wang et al., 2017, 2019; Fig. 1B), at the Laotougou Quarry section near the village of Erdaopuzi and along the main road (Zhang and Erdtmann, 2004; Yan et al., 2019).

\section{Biostratigraphy}

The acritarch, conodont, graptolite and trilobite biostratigraphy of the Xiaoyangqiao ASSP section is shown in Figs. 3 and 4. The acritarchs are in an early stage of revision, the trilobite succession has been described by Chen et al. $(1983,1985,1986)$ and outlined by Chen et al. (1988) and Wang et al. (2019), whereas brachiopods have not been investigated. The biostratigraphic subdivision of the Xiaoyangqiao ASSP section is based on the characteristic and well-known conodont evolutionary lineages and the planktonic graptolite evolution (Wang et al., 2019).

\section{Conodont Biostratigraphy}

The guide species of the Furongian and lowermost Ordovician are assigned to the euconodont genera Eoconodontus Miller, 1980 and
Cordylodus Pander, 1856 (Wang et al., 2019, fig. 3) (Fig. 3). The biozones are based on first appearances of the nominate taxa and the $E$. notchpeakensis, Cordylodus proavus, C. caboti, C. intermedius and $C$. lindstromi evolutionary zones are firmly established in the Xiaoyangqiao ASSP section (Wang et al., 2019; fig. 3) (Fig. 3). The younger C. angulatus and Rossodus manitouensis zones are recorded from the Yeli Formation in the Dayangcha area (Chen and Gong, 1986; Chen et al., 1988; Yan et al., 2019). The conodonts show a CAI of 1.5-2, which suggests that the host rocks were not heated above $140^{\circ} \mathrm{C}$ (Epstein et al., 1977).

\section{Acritarchs}

The acritarchs are of significance to assist in delineating faunal zones in the Furongian. The acritarch assemblages are based on continuous sampling of the whole section and the collection and the acritarch succession in the Xiaoyangqiao ASSP section is referred to three acritarch assemblages in the Cambrian-Ordovician boundary interval. The acritarch assemblages are currently under systematic revision, but they show great potential for correlation (Fig. 4; Wang et al., 2019). The acritarchs change their diversity pattern through the Cambrian-Ordovician interval.

\section{Graptolite Biostratigraphy}

Species of the genus Rhabdinopora Eichwald, 1855 have long been used as guide taxa in the lowermost Ordovician (Cooper et al., 1998; Maletz et al., 2017). Three biozones are recognized in the upper part of the Xiaoyangqiao ASSP section (unit IV) with well-preserved early Tremadocian graptolites. The fauna comprises Rhabdinopora proparabola (Lin, 1986), Rhabdinopora parabola (Bulman, 1954) and Anisograptus matanensis Ruedeman, 1937 and all of these are eponymous species of their graptolite biozones (Figs. 3, 4).

Rhabdinopora proparabola with its typical 'float' structure appears at $+20.9 \mathrm{~m}$ in the Xiaoyangqiao ASSP section (Fig. 3). Rhabdinopora parabola is a species that is widely distributed and known from Norway, Newfoundland, Canada and, Australia (Victoria). In the Xiaoyangqiao ASSP section Rhabdinopora parabola has been found in an interval at about five meters above $R$. proparabola. Anisograptus matanensis is present in a number of horizons about two and a half meters higher (at $+29.8 \mathrm{~m})$.

\section{Trilobite Biostratigraphy}

Trilobites are moderately common throughout the succession and are of Asian-Australian affinity. Most of them are endemic, a few of them provide, more or less, correlation tools of regional or intercontinental scale and allow tie lines to be established into some other Cambrian faunal realms. Particulary useful guide fossils are the few pandemic forms such as Mictosaukia spp., which are shared with Laurentia (Qian, 1986; Chen et al., 1988; Wang et al., 2019).

In summary, the FAD of Rhabdinopora proparabola is in the upper Cordylodus intermedius conodont Zone and $0.5 \mathrm{~m}$ below the base of the Cordylodus lindstromi conodont Zone (at $+21.4 \mathrm{~m})$. R. parabola appears within the Cordylodus lindstromi conodont Zone and Anisograptus matanensis is recorded from an interval that is equivalent to the upper part of the Cordylodus lindstromi conodont Zone (Figs. 3, 4). 


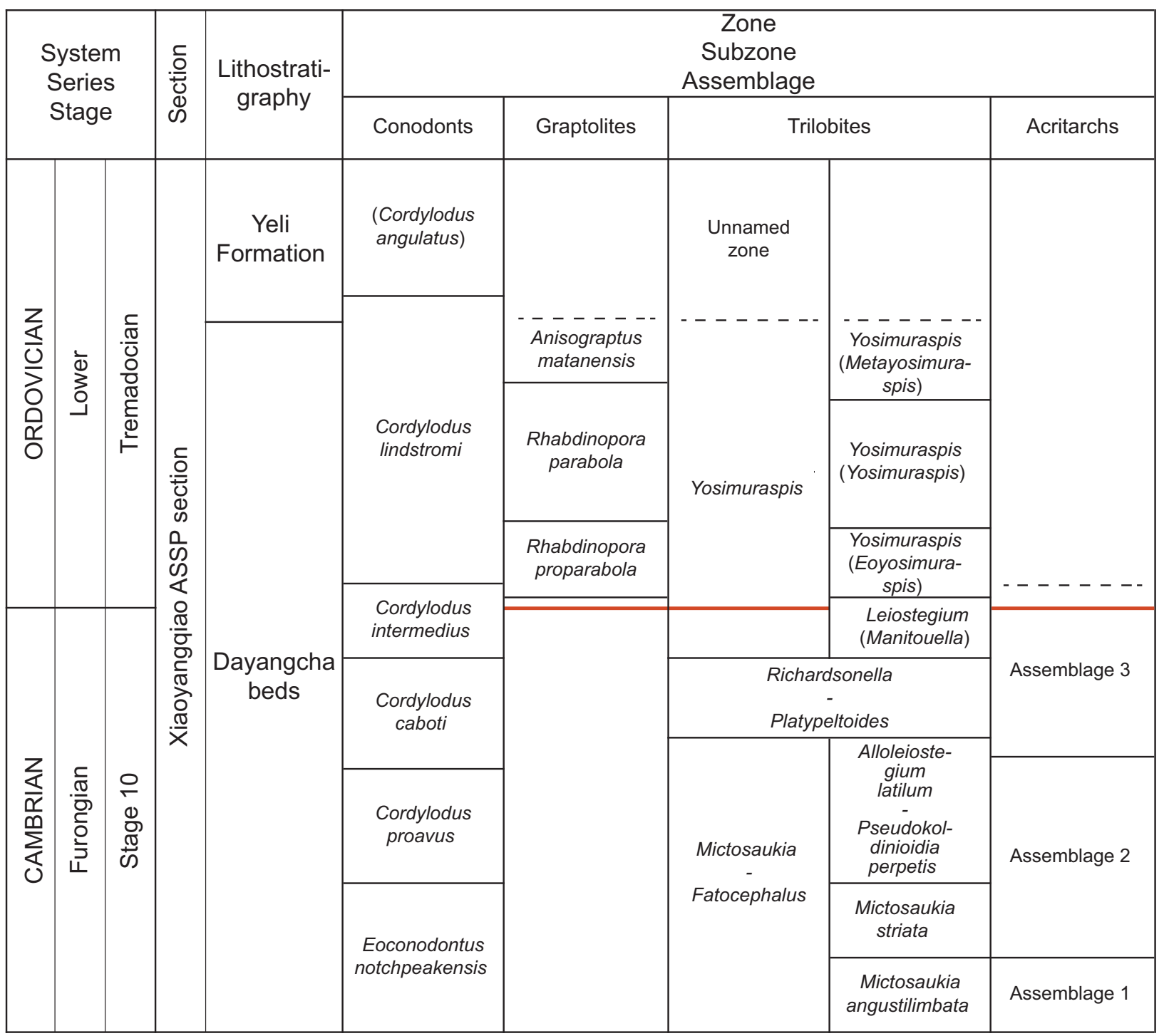

Figure 4. Integrated zonation systems modified from Chen (1986; trilobites), Chen et al. (1988; trilobites) and Wang et al. (2019, fig. 9). The red line is the interpreted position of the GSSP horizon.

\section{Sequence Stratigraphy and Sea Level}

The succession at the Xiaoyangqiao ASSP section is divided into three complete and two incomplete transgressive-regressive (TR) sedimentary cycles (sensu Embry and Johannessen, 1992), which represent $3^{\text {rd }}$, but more likely higher order, sedimentary cycles (Fig. 5; Wang et al., 2019). They are separated by conformable sequence boundaries (= maximum regressive surfaces, MRSs) within the top of the Eoconodontus notchpeakensis Zone, at about $-0.4 \mathrm{~m}$ below the reference level of the measured section, at ca. $+3.0 \mathrm{~m}$ below the top of the Cordylodus caboti Zone, and in the top of the $C$. intermedius Zone and below the base of the C. lindstromi and Rhabdinopora proparabola zones. Additional sequences of higher order are recognizable within these larger sedimentary cycles (Wang et al., 2019).

The sea-level record from the Xiaoyangqiao ASSP section exhibits four sea-level lowstands (Dayangcha 1 to 4 on Fig. 5) These are recorded at the base of the Cordylodus proavus Zone, at the transition from the upper Cordylodus caboti to the lower $C$. intermedius conodont zones, and at the top of the $C$. intermedius Zone and immediately below the base of the Rhabdinopora proparabola Zone and below the Cordylodus lindstromi conodont Zone.

\section{Chemostratigraphy}

\section{Carbon Isotope Chemostratigraphy}

The carbon isotopic composition of the carbonate rocks varies between 0.0 and +1.6 in the section (Fig. 6) and the carbon isotope record from the section exhibits four positive excursions. The first and most prominent excursion extends from the uppermost unit I (around $-1.1 \mathrm{~m}$ on Fig. 6 ) to the middle of unit III (around $+13.5 \mathrm{~m}$ on Fig. 6) with the highest value at 1.6 (Fig. 6; CPS = Cordylodus proavus Spike of Wang et al., 2019) occurring in the lower unit II, i.e., in the limestone beds below the stromatolite marker. The second positive excur- 


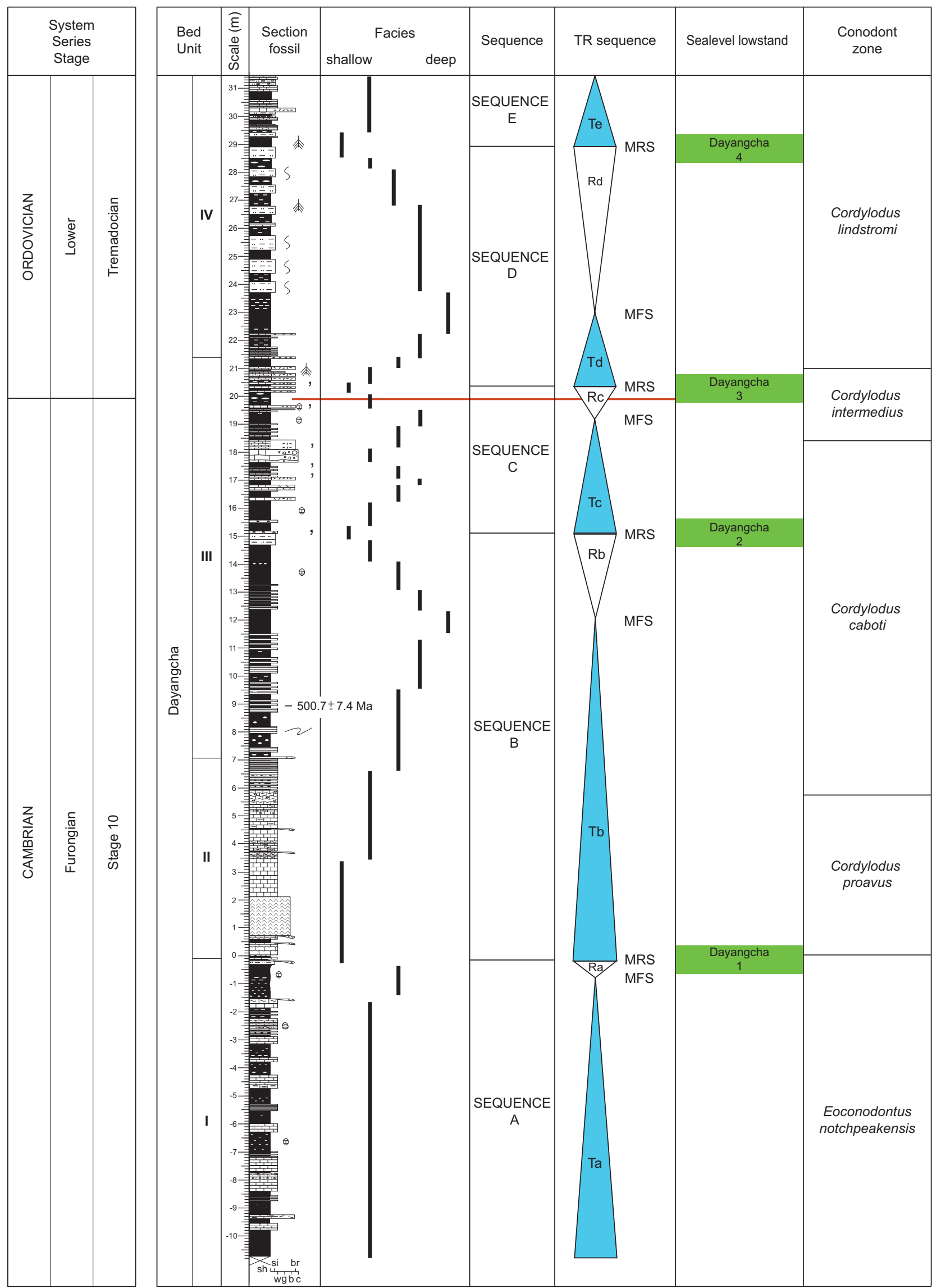

Figure 5. TR sequences and eustatic sea-level lowstands of the Xiaoyangqiao ASSP section (For legend see Fig. 8; modified from Wang et al. (2019). The red line is the interpreted position of the GSSP horizon. 
sion has $\delta^{13} \mathrm{C}$ values that progressively increase from 0.1 to the highest value ca. at 1.1 from the upper unit III (around $+17.3 \mathrm{~m}$ on Fig. 6 ; HSS $=$ the Hirsutodontus simplex (positive) Spike of Chen et al., 1995) and a decline to +0.2 ca at $+19.6 \mathrm{~m}$ ( 2 on Fig. 6 ). A pronounced shift from low positive values about 0.2 to high positive values occurs from $+19.6 \mathrm{~m}$ in the upper unit III and return to a minimum of +0.5 at $+23.6 \mathrm{~m}$ in

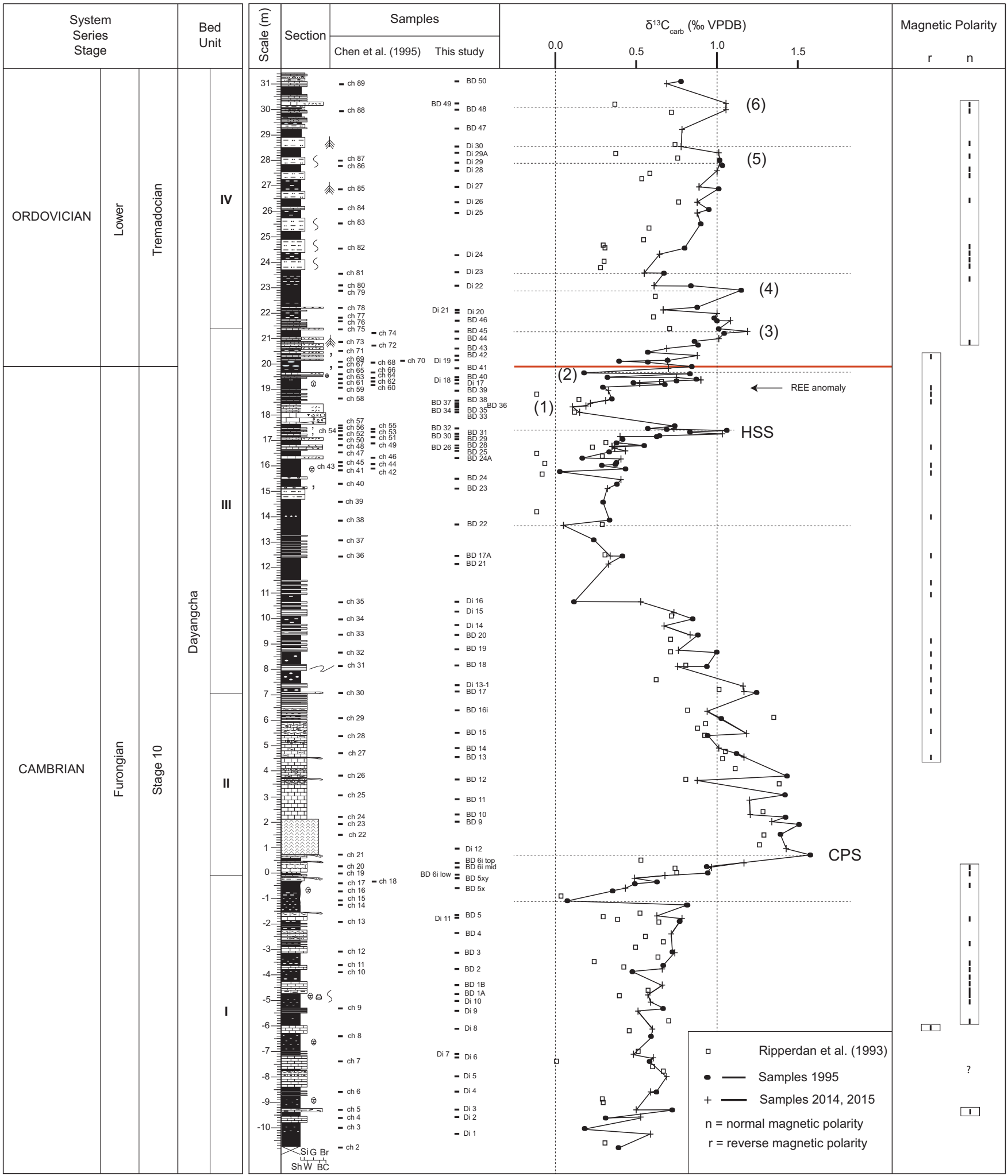

Figure 6. C-isotope curves and magnetic polarity data reversal from the Xiaoyangqiao ASSP section (modified from Wang et al., 2019, fig. 11). The data from Chen et al. (1995) and Wang et al. (2019) are outlined. (CPS = Cordylodus proavus Spike of Wang et al., 2019; HSS = Hirsutodontus simplex Spike of Chen et al., 1995). The number 1 to 7 are positive/negative spikes used for detailed correspondence. The red line is the interpreted position of the GSSP horizon. (For abbreviations, see caption to Fig. 3). 
unit IV. This excursion is first characterized by an interval with negative/positive fluctuations followed by a rise to two large positive peaks (3 and 4 on Fig. 6) The succeeding positive excursion from unit IV starting with low $\delta^{13} \mathrm{C}$ values gradually rise to around 1.0 to 1.1 (5 on Fig. 6) and a sharp decline at $+28.5 \mathrm{~m}$. The top of the section with an initial rise in values ( 6 on Fig. 6 ) represents the beginning of a new positive excursion, which is not completely recorded from this section.

The first positive excursion extends from the very top of the $E$. notchpeakensis Zone into middle of the $C$. caboti Zone. The second extends from the middle of the $C$. caboti Zone to the $C$. intermedius Zone. The excursion starting from the unnamed negative peak ( 2 on Fig. 6; Wang et al., 2019, fig. 11) is from within the upper Cordylodus intermedius Zone and the succeeding prominent positive peaks ( 3 and 4 on Fig. 6) are recorded from immediately above the base of the Cordylodus lindstromi Zone and above the base of the Rhabdinopora proparabola Zone. This positive excursion with the two prominent peaks is associated with the appearance of planktonic graptolites. The higher isotope peak at $28.0 \mathrm{~m}$ (5 on Fig. 6) lies within the upper $R$. parabola Zone and the top peak in the section (6 on Fig. 6) is situated just above the base of the Anisograptus matanensis Zone.

\section{Rare Earth Elements (REE)}

A REE anomaly - using brachiopod apatite - peaks at ca. $+18.2 \mathrm{~m}$ in the upper part of lithological unit III (Chen et al., 1986). The anomaly is extending from within the top of the Cordylodus caboti into the lower Cordylodus intermedius Zone and below the MFS of sequence C (at +19.2 $\mathrm{m}$ ), which is below the Cambrian-Ordovician boundary (Wang et al., 2019, fig. 11) (Fig. 6). The significance of this REE is not known.

\section{Magnetostratigraphy}

Two reverse and two normal polarity zones are detected in the Dayangcha beds between ca. -6.3 m (unit I) and + $30.2 \mathrm{~m}$ (unit IV) (Ripperdan and Kirschvink, 1992; Chen et al., 1995; Wang et al., 2019, fig. 11) (Fig. 6). In ascending order a short reversed interval (-6.3 $\mathrm{m}$ to $-4.5 \mathrm{~m}$ ) was detected in the middle part of unit I (Eoconodontus notchpeakensis Zone). A normal interval occurs from $-4.4 \mathrm{~m}$ to $+0.4 \mathrm{~m}$ in upper unit I and into the lower unit II (top Eoconodontus notchpeakensis Zone). From $+0.4 \mathrm{~m}$ to $+4.3 \mathrm{~m}$ there are no data. In unit III and at $+4.3 \mathrm{~m}$ an extensive reverse polarity zone is initiated and it extends up to $+20.4 \mathrm{~m}$ (comprising the Cordylodus proavus and C. caboti zones and most of $C$. intermedius Zone). At $+20.5 \mathrm{~m}$ and at the top of unit III the magnetic polarity change to normal that persists up to $+30.2 \mathrm{~m}$. This upper shift from reverse to normal polarity is remarkable as it occurs in the upper $C$. intermedius Zone immediately above the proposed Cambrian-Ordovician boundary level (at $+19.9 \mathrm{~m}$; see below) and immediately below the FAD of planktonic graptolites (at $+20.9 \mathrm{~m}$ ), and the C. lindstromi conodont Zone (at $+21,4 \mathrm{~m}$ ).

\section{Correlation to the Green Point GSSP section, Western Newfoundland, Canada}

The Green Point GSSP section is exposed in the coastal cliff about
$10 \mathrm{~km}$ north of the village of Rocky Harbour, western Newfoundland, Canada (James and Stevens, 1986; Cooper et al., 2001; Stouge et al., 2017). The GSSP section covers an interval from late Cambrian (upper Stage 10; Furongian) to the Tremadocian (Lower Ordovician). The section is well-documented in terms of lithology, palaeontology and biostratigraphy (James and Stevens, 1986; Bagnoli et al., 1987; Erdtmann, 1988; Cooper et al., 1998, 2001; Terfelt et al., 2012; Pouille et al., 2014 and references therein; Stouge et al., 2017 and references therein; Wang et al., 2019). Non-biotic high-resolution data have been presented by Azmi et al. (2014), and Stouge et al. (2017). Fortey et al. (1982), James and Stevens (1986), Bagnoli et al. (1987), Barnes (1988) and Stouge et al. (2017) provided further information on the Cambrian-Ordovician transition from additional sections in the area.

The deep-water Cambrian-Middle Ordovician strata of the Laurentian slope are referred to the Cow Head Group (Kindle and Whittington, 1958). The exposed strata at the Green Point GSSP section are assigned to the Martin Point and Broom Point members of the Green Point Formation (James and Stevens, 1986). The succession consists of parted and ribbon limestone (terminology of James and Stevens, 1986, p. 27; i.e., interbedded limestone and shale) and a few breccia beds that were deposited in a lower to toe-of slope depositional environment. The strata are exposed in one limb of an overturned unnamed anticline.

Palaeogeographically, the Green Point GSSP section is situated on the eastern slope of the Laurentian palaeocontinental margin. The section yields important fossils including conodonts, radiolarians and a few trilobites. Conodonts and graptolites in the Green Point GSSP section are the most important fossil groups for intercontinental correlation. Non-biotic markers include $\delta^{13} \mathrm{C}$ isotopes, and sea-level changes.

\section{Biostratigraphic Correlation}

The base of the Ordovician in the Green Point GSSP section is fixed at $+8.8 \mathrm{~m}$ within unit 23 of the Broom Point Member of the Green Point Formation (James and Stevens, 1986; Cooper et al., 2001) (Fig. 7). The boundary is a lensoid to lenticular, bedded limestone bed developed within a ribbon to parted limestone unit (Cooper et al., 2001).

The biological marker for the GSSP horizon is Iapetognathus preaengensis Landing in Fortey et al., 1982 (i.e., Barnes, 1988; Terfelt et al., 2012). I. preaengensis has also been recorded from northern Europe (Bruton et al., 1982, 1988; Kaljo et al., 1986).

The correlation criteria used here are the Cordylodus evolutionary lineage and the FAD and succession of planktonic graptolites. The conodonts are light yellow, displaying a CAI of 1 to 1.5 of Epstein et al. (1977).

\section{Conodonts}

The Cordylodus intermedius and C. angulatus zones are precisely established in the Green Point GSSP section. Cordylodus caboti Bagnoli, Barnes and Stevens, 1987 is present in the section, but the base of this zone has not been established precisely here (Bagnoli et al., 1987; Barnes, 1988; Cooper et al., 2001). The two first zones correlate directly with the same interval zones established in the Xiaoyangqiao ASSP section (Fig. 8). The strata - coeval with the C. lindstromi Zone - are developed in graptolite facies (units 25 and 26) and without the 


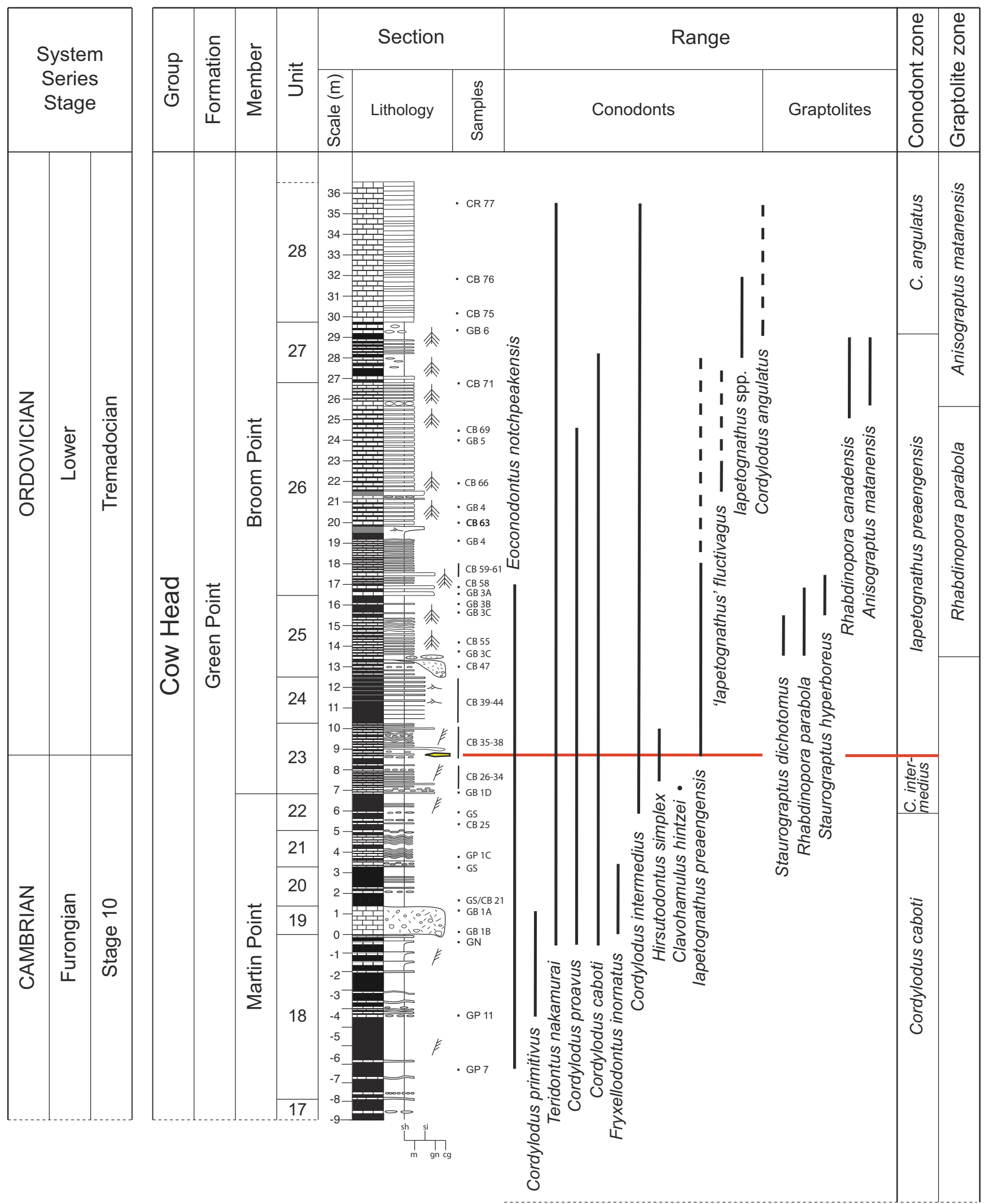

Figure 7. The Green Point GSSP section, Western Newfoundland, Canada. Ranges of conodonts and graptolite species are shown. The 'Golden Spike' is placed in the upper unit 23 and at the first appearance of Iapetognathus preaengensis. The position of 'Iapetognathus' fluctivagus in unit 26 is from Terfelt et al. (2012) and Barnes (1988) (modified from fig. 12 in Wang et al., 2019). (For abbreviations, see caption to Fig. 3; for legend see Fig. 8). The red line marks the GSSP horizon. The position and ranges of Iapetognathus praeangensis and 'Iapetognath us' fluctivagus are adopted from Terfelt et al. (2012). Modified from Wang et al. (2019). 


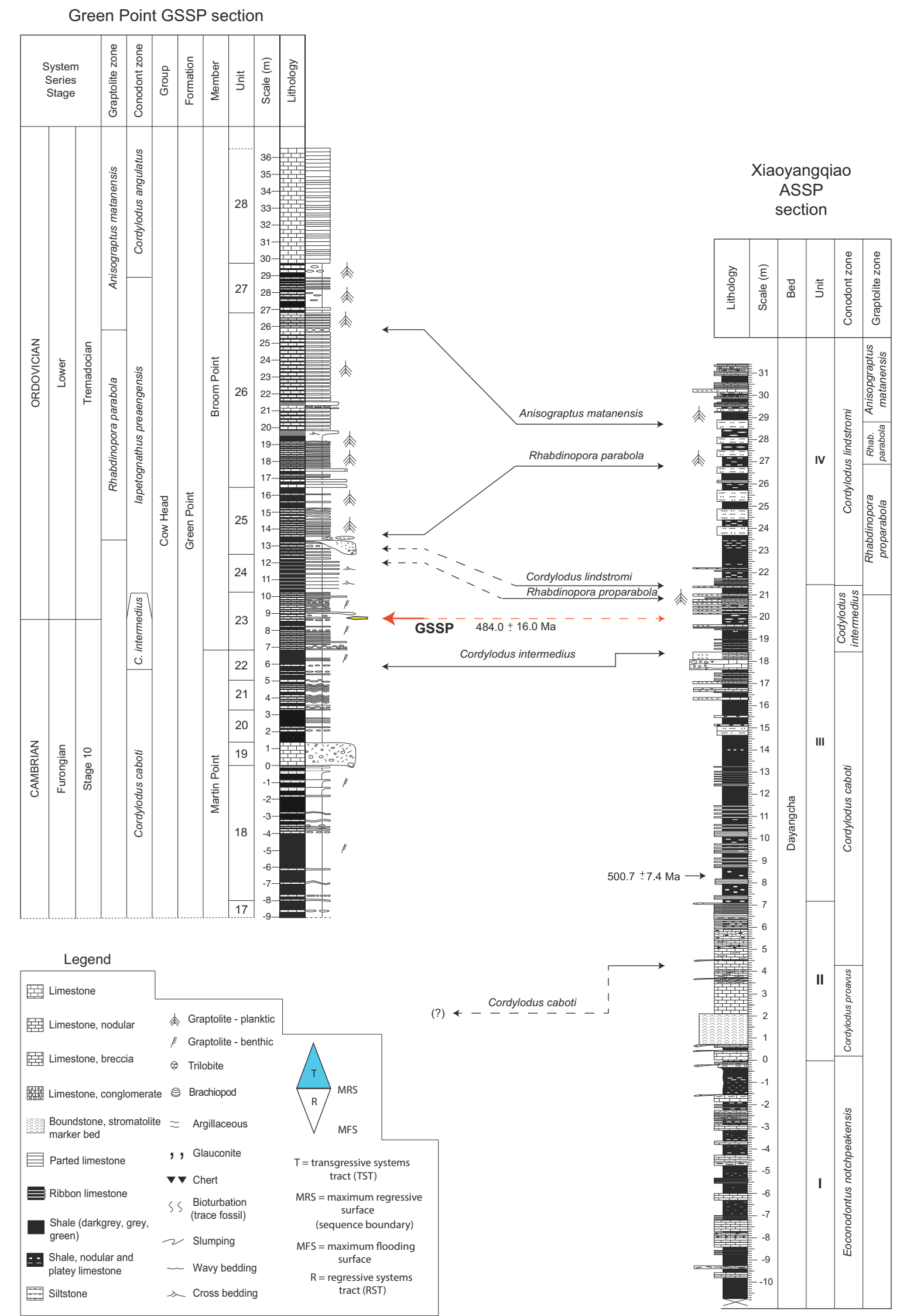

Figure 8. Biostratigraphic correlation of the Xiaoyangqiao ASSP section and the Green Point GSSP section; dashed lines represent the proposed or likely correlation with the GSSP horizon and the correlation of a taxon that is represented in only one of the two sections (modified from Wang et al., 2019). The absolute ages are from Yang et al. (1986) and Tripathy et al. (2014), respectively. The red line is the GSSP horizon. 
eponymous conodont species. The species Cordylodus caboti, C. proavus Müller, 1959 and C. intermedius Furnish, 1938 from below range through these strata and occur together with additional Cordylodus species (i.e., Cordylodus prion Lindström, 1955 and C. hastatus Barnes, 1988) that are not used for correlation. Specimens of the genus Iapetognathus Nicoll et al., 1999 including the GSSP marker I. preaengensis Landing in Fortey et al., 1982 from unit 23 and I. aengensis (Lindström, 1955) are recorded from unit 27 (Barnes, 1988; Cooper et al., 2001; Stouge et al., 2017; Wang et al., 2019). 'Iapetognathus' fluctivagus Nicoll et al., 1999 is recorded from the deposits of unit 26 (Terfelt et al., 2012; Wang et al., 2019).

\section{Graptolites}

Rhabdinopora parabola and Anisograptus matanensis are characteristic of the diverse graptolite succession in the section (Fig. 6; Cooper et al., 1998, 2001). Also, the presence of species of the genus Staurograptus Emmons, 1855 are characteristic of the Green Point GSSP section. The first appearances of Rhabdinopora parabola (note: $R$. praeparabola (Bruton, Erdtmann and Koch, 1982)) is now synonymized with $R$. parabola; Maletz et al., 2017) and Staurograptus dichotomus Emmons, 1855 are in unit 25; it is succeeded by $R$. flabelliformis (Eichwald, 1840) and S. hyperboreus Obut and Sobolevskaja, 1962. Cooper et al. $(1998,2001)$ assigned this association of graptolite species to Assemblage 1. Anisograptus matanensis and Rhadinopora canadensis (Lapworth, 1898) both appear in the uppermost portion of unit 26 and up-section, and are followed by $R$. anglica (Bulman, 1927) in unit 29. Combined, these taxa represent Assemblage 2 or the Anisograptus matanensis Zone (Erdtmann, 1986; Cooper et al., 1998; Cooper, 1999; Cooper et al., 2001). The Rhabdinopora parabola and Anisograptus matanensis zones clearly correlate with the zones of the Xiaoyangqiao ASSP section, whereas the first planktonic graptolite Rhabdinopora proparabola has not been recorded in the Green Point GSSP section. Fig. 8 shows the correlation between the Green Point GSSP section and the Xiaoyangqiao ASSP section.

\section{Non-biotic Match}

The high-resolution $\delta^{13} \mathrm{C}_{\text {carb }}$-isotope curve from the Green Point GSSP section (Fig. 9; Azmy et al., 2014; Stouge et al., 2017; Wang et al., 2019) show similar pattern as compared with the Xiaoyangqiao ASSP section and the positive excursions recorded from the Xiaoyangqiao ASSP section (Fig. 6; Wang et al., 2019) can be identified. The positive $\delta^{13} \mathrm{C}$ excursion of the Green Point GSSP section with a positive maximum peak at $\mathrm{ca}+6 \mathrm{~m}$ is similar to the positive HSS spike of the Xiaoyangxiao ASSP section and the following decrease towards the negative values (1 and 2 on Fig. 9; Wang et al., 2019, fig. 15) can be matched. The upper of the two negative spikes (i.e., 2 on Fig. 9 ) is situated below the GSSP horizon. The following positive excursion with the prominent increase in $\delta^{13} \mathrm{C}$ isotope values of the Green Point GSSP section to the maximum positive values of spikes 3 and 4 above the GSSP horizon is characteristic (Figs. 9, 10). This general C isotope curve outline was also noted by Cooper et al. (2001), Azmy et al. (2014), Stouge et al. (2017) and Wang et al. (2019). The $\delta^{13} \mathrm{C}_{\text {carb }}$-isotope peak 3 is the largest positive value in the two sections and corresponds to the first appearance of planktonic graptolites in the Green
Point GSSP section. The upwards following C isotope excursion (4 on Fig. 9) also provides a match between the two sections (Fig. 10).

The Cambrian-Ordovician boundary stratotype horizon separates the negative peak (Fig. 9, no. 2) in the uppermost Cambrian to high positive $\delta^{13} \mathrm{C}$ values (Fig. 9, nos. 3 and 4) of the Lower Ordovician.

The change from the reverse magnetic polarity in the latest Cambrian to the normal magnetic polarity in earliest Ordovician is observed only in the Xiaoyangqiao ASSP section (Fig. 5). However, this match suggests that all the sediments with the rise of planktonic graptolites belong to the Ordovician.

A REE anomaly lies between HSS and the negative C-isotope excursions in both sections. As mentioned above the significance of these REE anomalies are not known (cf., Azmi et al., 2014).

\section{Comparison of Sea Level}

In the Green Point GSSP section the record of sea-level lows (Fig. 9) shows similar pattern as for the Xiaoyangqiao ASSP section (Figs. 5, 11). The Dayangcha 2 lowstand at the zonal transition from the Cordylodus caboti - basal Cordylodus intermedius zones of the Xiaoyangqiao ASSP Section corresponds to the lowstand displayed by units 19 and 20 in the Green Point GSSP section and is named the Basal House lowstand (Cooper et al., 2001). The Dayangcha 3 lowstand or regressive event from the top of the Cordylodus intermedius to the base of C. lindstromi zones in the Xiaoyangqiao ASSP Section is coeval with the silt and fine sandstone lowstand deposits of unit 24 of the Green Point GSSP section, which is assigned to the global ARE eustatic lowstand in the Green Point GSSP section (cf., Cooper, 1999; Cooper et al., 2001; Wang et al., 2019).

\section{The Position of the ASSP Level in the Xiao- yangqiao Section}

The ASSP level for the base of the Ordovician System is identified by biostratigraphy, TR sequences, sea-level lowstand and $\delta^{13} \mathrm{C}_{\text {carb }}$-isotope trends within the upper unit III in the Xiaoyangqiao ASSP section. According to Wang et al. (2019) the correlative level to the GSSP horizon in the Green Point FSP section is ca at $+19.9 \mathrm{~m}( \pm 0.2 \mathrm{~m})$ above the reference level (Figs. 10, 11). Following this interpretation, the ASSP horizon or the Cambrian-Ordovician boundary lies within the upper part of the Cordylodus intermedius Zone in the Xioayangxiao ASSP section. The boundary horizon is within a relatively monotonous succession, rich in trilobites and composed of interbedded shale and bedded to nodular limestone beds. The appearance of the first planktonic graptolite Rhabdinopora proparabola, recorded at $+20.9 \mathrm{~m}$ above the zero-datum level of the section, is $1.0 \mathrm{~m}$ above the proposed ASSP level at $+19.9 \mathrm{~m}( \pm 0.2 \mathrm{~m})$.

\section{Correlation to the Wa'ergang Section, Hunan, South China}

The Wa'ergang section is exposed mainly in a roadcut at the village of Wa'ergang, Taoyuan, Hunan, South China and lies about $10 \mathrm{~km}$ 


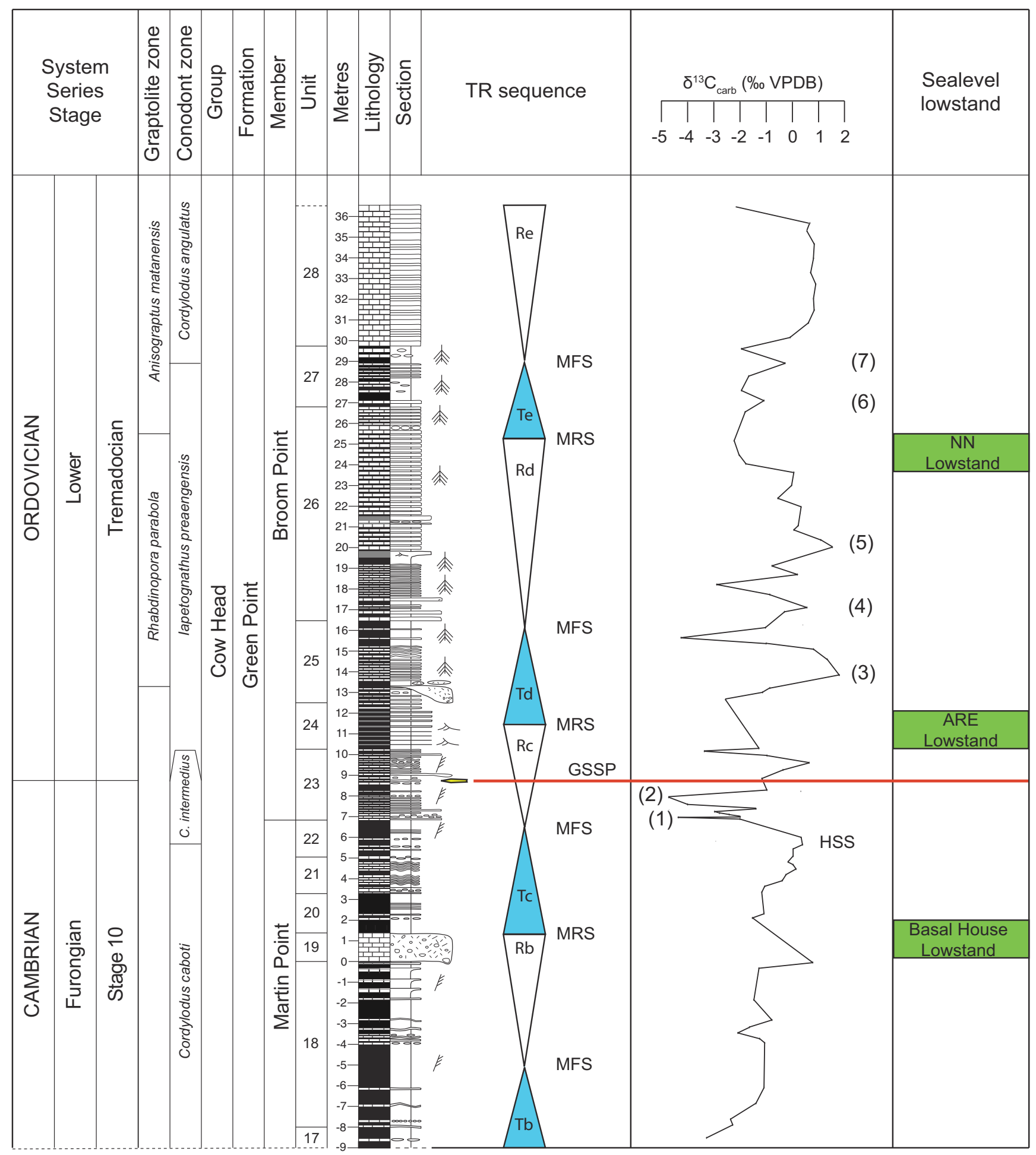

Figure 9. TR sequences, C-isotopes curve and sea-level lowstand from the Green Point GSSP section. The red line is the position of the GSSP horizon. The names of the lowstands are from Cooper et al. (2001); NN= no name) (modified from Stouge et al. 2017; Wang et al., 2019, fig. 11). (For abbreviations, see caption to Figure 3).

northwest of Niuchehe Town. The Wa'ergang section is well documented in terms of lithology, palaeontology and biostratigraphy (Lu, 1984; Lu and Lin, 1984; Peng, 1984, 2009a, b; Peng et al., 2012; Dong and Zhang, 2017 and references therein). The thick Cambrian-Ordovician succession is assigned to the Huaqiao, Shenjiawan and Panjiazui formations, which consist of carbonate and argillaceous sedimentary rocks that were deposited in a lower slope to basinal environment. It lies on the southern limb of an unnamed syncline extending along the border between Taoyuan County and Zhangjiajie City.

Palaeogeographically, the Wa'ergang section is situated in the Jiangnan Slope Belt of South China. Important fossil groups for correlation in the Wa'ergan section are trilobites and conodonts. 

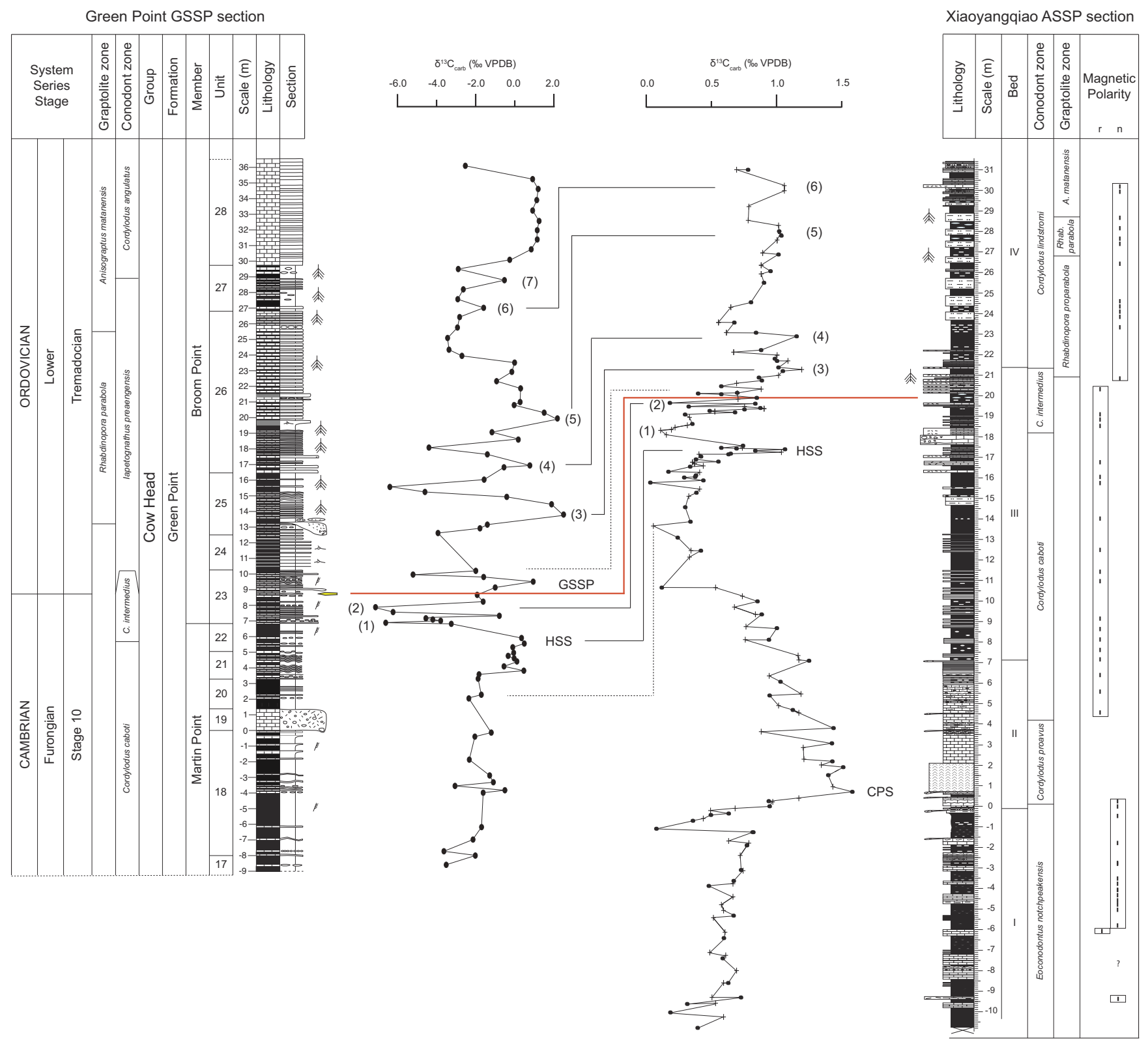

Figure 10. Interpreted match of C-isotope curves between the Green Point GSSP section and the Xiaoyangqiao ASSP section. The red line it the GSSP horizon.

\section{Biostratigraphic Correlation}

\section{Conodonts}

Dong and Zhang (2017) established a series of para- and euconodont zones from the section spanning the Miaolingian (Cambrian) into the Tremadocian (Lower Ordovician). In the interval from the upper Cambrian to the Lower Ordovician, the presence of Eoconodontus notchpeakensis (Miller, 1969) and the complete evolutionary series of Cordylodus species are recorded. The zones of interest for correlation here are those of the Eoconodontus, Cordylodus proavus, Cordylodus intermedius, (lower and upper) Cordylodus lindstromi and Cordylodus angulatus (lower part). As for the Xiaoyangqiao ASSP section all the named taxa are nominate species and correlation to the Xiao- yangqiao ASSP section is easy. However, Dong and Zhang (2017) did not identify the Cordylodus caboti Zone and the C. intermedius Zone overlies directly on the C. proavus Zone in the Wa'ergang section, which is a difference from the zonation established at the Xiaoyangqiao ASSP section.

Significant is the presence of (in successive order) Iapetognathus jilinensis Nicoll et al., 1999, 'Iapetognathus' fluctivagus and Iapetognathus aengensis in the Wa'ergang section. As for the Xiaoyangqiao ASSP section I. jilinensis is in the Wa'ergang section is recorded from just above the base of the Cordylodus lindstromi Zone (ca at $632 \mathrm{~m}$ = lower C. lindstromi Zone of Dong and Zhang, 2017, fig. 3). It is succeeded by 'Iapetognathus' fluctivagus at a stratigraphically higher level (i.e., ca. at $702 \mathrm{~m}$; = upper Cordylodus lindstromi Zone of Dong and Zhang, 2017, fig. 3) within the Cordylodus lindstromi Zone. I. 


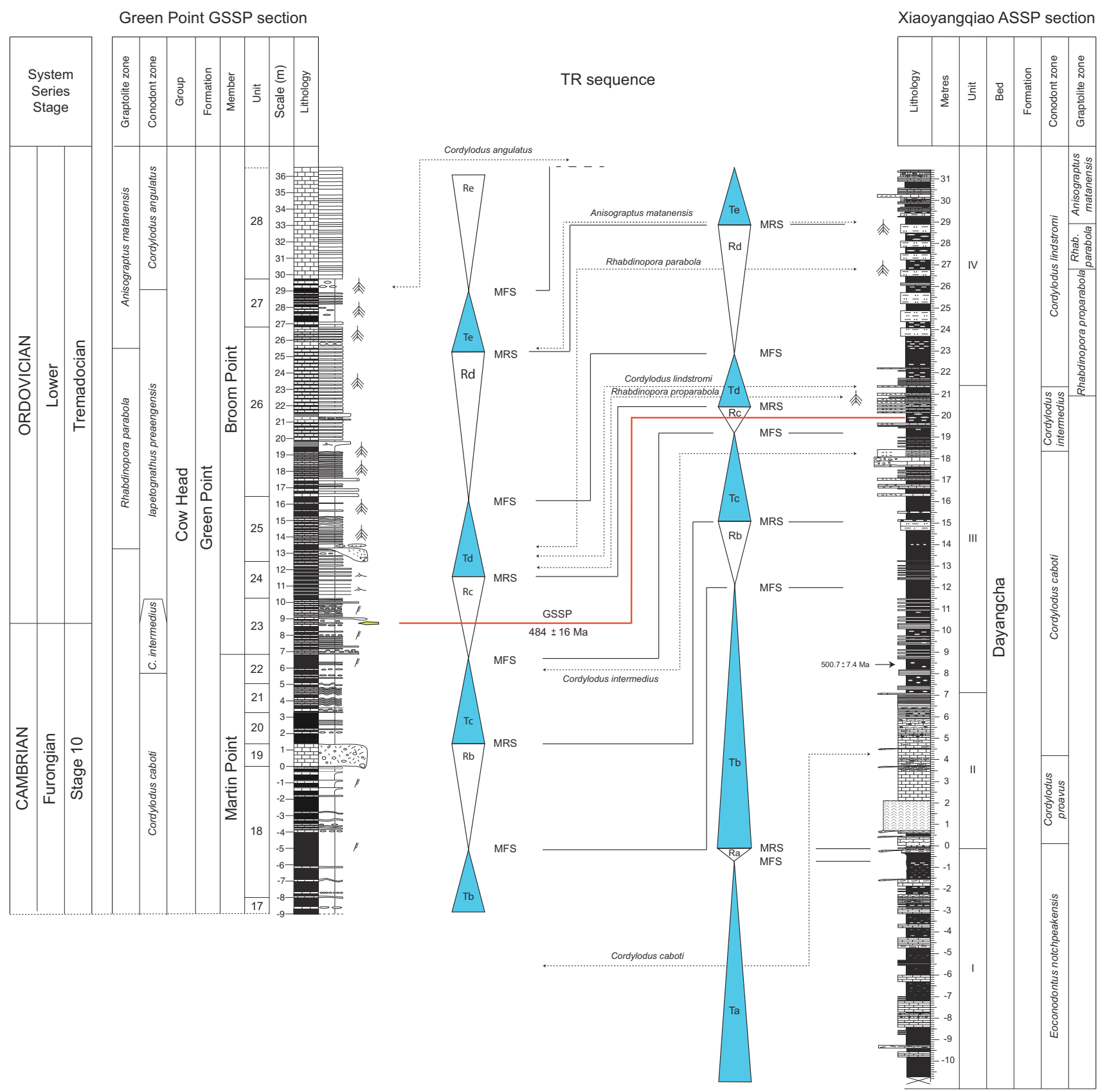

Figure 11. Comparison of TR cycles between Green Point GSSP section and the Xiaoyangqiao ASSP section. The red line is the GSSP horizon and its proposed position in the Xiaoyangqiao ASSP section. Green Boxes represent identified and named sea-level lowstands in the two sections.

aengensis appears together with Cordylodus angulatus in the Wa'ergang section.

\section{Trilobites}

The well-preserved Cambrian and Ordovician trilobite fauna from the Wa'ergan section has been described by many authors and summarized by Peng (2009a, b) and Peng et al. (2012). The detailed trilobite biostratigraphy can be correlated to the upper Cambrian to Lower Ordovician conodont zonation (Dong and Zhang, 2017).

\section{Correlation to the Lawson ASSP Section, Utah, USA}

The Lawson Cove ASSP section lies within the Ibex Area of Millard County, Utah, USA. The Cambrian-Ordovician succession is here about $5300 \mathrm{~m}$ thick and composed of shallow water limestone typical of a tropical, shelly facies carbonate platform. The upper Cambrian to Lower Ordovician succession is about $240 \mathrm{~m}$ thick. The strata at the Lawson Cove ASSP section are assigned to the upper Notch Peak Formation and the House Limestone, the latter of which is the lowest 
formation of the Pogonip Group (Miller et al., 2003). Both formations are subdivided into three members.

The faunal succession at the Lawson Cove ASSP section has been investigated in great detail and is rich in shelly fossils, including trilobites and brachiopods (e.g., Hintze 1951, 1953; Popov et al., 2002; Adrain and Westrop, 2006), and conodonts (Miller et al., 2015 with references). The conodont biostratigraphy has been outlined many times by Miller (1969, 1980, 2020) and Miller et al. (e.g., 1982, 2003, 2012, 2015 and references therein). The proposed ASSP level in the Lawson Cove ASSP section is at the base of the Iapetognathus Zone (Miller et al., 2014, 2015). Non-biotic signals comprise $\delta^{13} \mathrm{C}_{\text {carb }}$-isotopes (Ripperdan and Miller, 1995) and sequence stratigraphy (Miller et al., 2003).

Palaeogeographically, the deposits exposed in the Lawson Cove ASSP section are part of the Great American Carbonate platform of the Laurentian palaeocontinent (Miller et al., 2012). The most important fossil group for intercontinental correlation in the Lawson Cove ASSP section is the conodonts. Trilobite and brachiopod assemblages are useful for regional correlation.

\section{Biostratigraphic Correlation}

\section{Conodonts}

The upper Cambrian to Lower Ordovician succession of the Lawson Cove ASSP section is divided into several euconodont zones and subzones. The lowermost part of the section is assigned to the Proconodontus conodont Zone; here the correlation begins with the overlying Eoconodontus Zone.

The Eoconodontus Zone of western USA (Miller, 1988) is characterized by the presence of Eoconodontus notchpeakensis, but the zone here differs from that in other places in its definition of the top of the zone. The Eoconodontus Zone is subdivided into the Eoconodontus notchpeakensis Subzone and the Cambroistodus minutus Subzone. The latter subzone is distinguished as the Cambrooistodus Zone at Dayangcha (Chen and Gong, 1986).

The overlying Cordylodus proavus Zone is characterized by the presence of $C$. proavus, but the base of the biozone is defined by the first occurrence of 'Cordylodus' andresi Viira and Sergeyeva, 1987 in Viira et al., 1987. 'Cordylodus' andresi is recorded in the Xiaoyangqiao ASSP section at $-1.9 \mathrm{~m}$, ranging to $+0.4 \mathrm{~m}$, which is below the FAD of Cordylodus proavus at $+0.6 \mathrm{~m}$ (Fig. 3; Wang et al., 2019). Thus, the base of the Cordylodus proavus Zone in the Lawson Cove ASSP section lies below the defined base of the Cordylodus proavus Zone in the Xiaoyangqiao ASSP section.

The Cordylodus proavus Zone in the Lawson Cove ASSP section is subdivided into the Hirsutodontus hirsutus, Fryxellodontus inornatus and Clavahamulus elongatus shallow water subzones. Fryxellodontus inornatus Miller, 1969 is present in the Xiaoyangqiao ASSP section with a range within the $C$. proavus Zone. The $H$. hirsutus and $C$. elongatus subzones are not identified in the Xiaoyangqiao ASSP section, because these two subzonal nominate species are absent. As for the Wa'ergang section, the Cordylodus caboti Zone is not distinguished in the Lawson Cove ASSP section (e.g., Miller et al., 2015 with references) as done in the Xiaoyangqiao ASSP and Green Point GSSP sections.

In western USA, the base of the next zone, the $C$. intermedius Zone, is commonly defined at the lowest occurrence of several species including
Hirsutodontus simplex (Druce and Jones, 1971), Monocostodus sevierensis (Miller, 1969) and Utahcononus utahensis (Miller, 1969) and succeeded by Cordylodus intermedius Furnish, 1938. According to the ranges in the Lawson Cove ASSP section (e.g. Miller et al., 2015, fig. 8) the three first mentioned species appear below the first occurrence (FO) of Cordylodus intermedius and together these taxa define the Hirsutodontus simplex Subzone of the Cordylodus intermedius Zone. The Clavohamulus hintzei Subzone is the upper subzone of the Cordylodus intermedius Zone.

The appearance of $H$. simplex below the FAD of $C$. intermedius is similar to the Xiaoyangqiao ASSP section, whereas the Clavohamulus hintzei Subzone has not been distinguished in the Xiaoyangqiao ASSP section due to the lack of the subzonal index species. The base of the $C$. intermedius Zone in the Xiaoyangqiao ASSP section corresponds to a level within the $C$. intermedius Zone as defined in the Lawson Cove ASSP section.

In the Lawson Cove ASSP section the Cordylodus lindstromi sensu lato Zone is marked by the appearance of Cordylodus prolindstromi Nicoll, 1999, extending to the appearance of 'Iapetognathus' fluctivagus. Cordylodus lindstromi Druce and Jones, 1971 sensu stricto defines the base of the upper subzone of the Cordylodus lindstromi sensu lato Zone of Miller et al. (2015). C. prolindstromi appears at $+20.6 \mathrm{~m}$ in the Xiaoyangqiao ASSP section (Wang et al., 2019), and this level may correspond to the base of the lower $C$. lindstromi subzone in the Lawson Cove ASSP section. C. lindstromi appears at $+21.4 \mathrm{~m}$ in the Xiaoyangqiao ASSP section and the $C$. lindstromi Zone correlates with the upper subzone of the $C$. lindstromi sensu lato Zone of the Lawson Cove ASSP section.

The Iapetognathus Zone of Miller et al. (2015) comprises the interval from the appearance of 'Iapetognathus' fluctivagus to the base of the Cordylodus angulatus Zone. The biozone has not been identified in the Xiaoyangqiao ASSP section, because the nominate taxon is absent in the succession. Instead, the species Iapetognathus jilinensis appears in the lower $C$. lindstromi Zone in the Xiaoyangqiao ASSP section, but this species has not been recorded from the Lawson Cove ASSP section.

Nicoll et al. (1999) proposed that the genus Iapetonudus Nicoll et al., 1999 (type species: I. ibexensis Nicoll et al., 1999) could be the ancestor of the genus Iapetognathus. However, this interpretation is difficult to accept, because (1) the genus Iapetonudus is first recorded from the base of the Iapetognathus Zone in the Lawson Cove ASSP section, where it occurs together with 'Iapetognathus' fluctivagus (e.g., Nicoll et al., 1999; Miller et al., 2015, fig. 8) and (2) two of its potential 'successors' (= Iapetognathus preaengensis and I. jilinensis) appeared earlier (i.e., in the upper $C$. intermedius Zone and lower C. lindstromi Zone, respectively) than their proposed ancestor (i.e., in the Iapetognathus Zone). Instead, the genus Iapetonudus may be the ancestor of 'Iapetognathus' fluctivagus, but until this is confirmed, the latter species is here referred to as 'Iapetognathus' fluctivagus (following Terfelt et al., 2012).

Like in most other sections, the Cordylodus angulatus Zone of the Lawson Cove ASSP section is defined by the appearance of the epinymous taxon and is easy to correlate. Previously, the zone was named Cordylodus angulatus-Chosonodina herfurthi Zone by Chen and Gong (1986), but here it is simply renamed as the Cordylodus angulatus Zone (following Yan et al., 2019). The Cordylodus angulatus Zone is 
recognized worldwide.

\section{Trilobites}

The trilobite zonation of the Lawson Cove ASSP Section comprises several zonal and subzonal units (Ross et al., 1997). The trilobite zones are broadly defined and used mainly for regional correlation. However, the appearance in the Lawson Cove ASSP section of the hystricurid genus Millardicurus Adrian and Westrop, 2006 within the Symphysurina trilobite Zone, corresponding to the upper Cordylodus intermedius conodont Zone, is close to the base of the global Ordovician System (cf., ranges in Miller et al., 2015, fig. 11; see also Adrain and Westrop, 2006). The occurrence of the pelagic olenid trilobite Jujuyaspis borealis Kobayashi, 1955 is from a higher level in the section i.e., at $161.5 \mathrm{~m}$, which is $0.90 \mathrm{~m}$ above the base of the Iapetognathus conodont Zone.

\section{Graptolites}

Graptolites have not been recorded from the Lawson Cove ASSP section. However, Anisograptus matanensis has been found in a single horizon in the Iapetognathus Zone in the Lavadam North section, which lies about $25 \mathrm{~km}$ from the Lawson ASSP section. The presence of $A$. matanensis suggests correlation with the A. matanensis Zone in the Xiaoyangqiao ASSP section and the Green Point GSSP section.

\section{Non-biotic Match}

\section{C-isotopes}

The $\delta^{13} \mathrm{C}$ curve from the Lawson Cove ASSP section shows a number of prominent positive excursion with maximum and minimum peaks - and these were given numbers (Fig. 12; Ripperdan and Miller, 1995; Miller et al. 2014, 2015). Of these, the swing from positive peak 8 to low positive peak 9 with a prominent return to the high positive peak 10 (i.e., immediately above 1.0) corresponds directly with the isotope trend in the Xiaoyangqiao ASSP section, where the positive peak 10 of Lawson Cove ASSP section corresponds to the 'Cordylodus proavus spike' (CPS) of Wang et al. (2019; Fig. 12). This pattern represents a precise match between the two sections and it is biostrati-

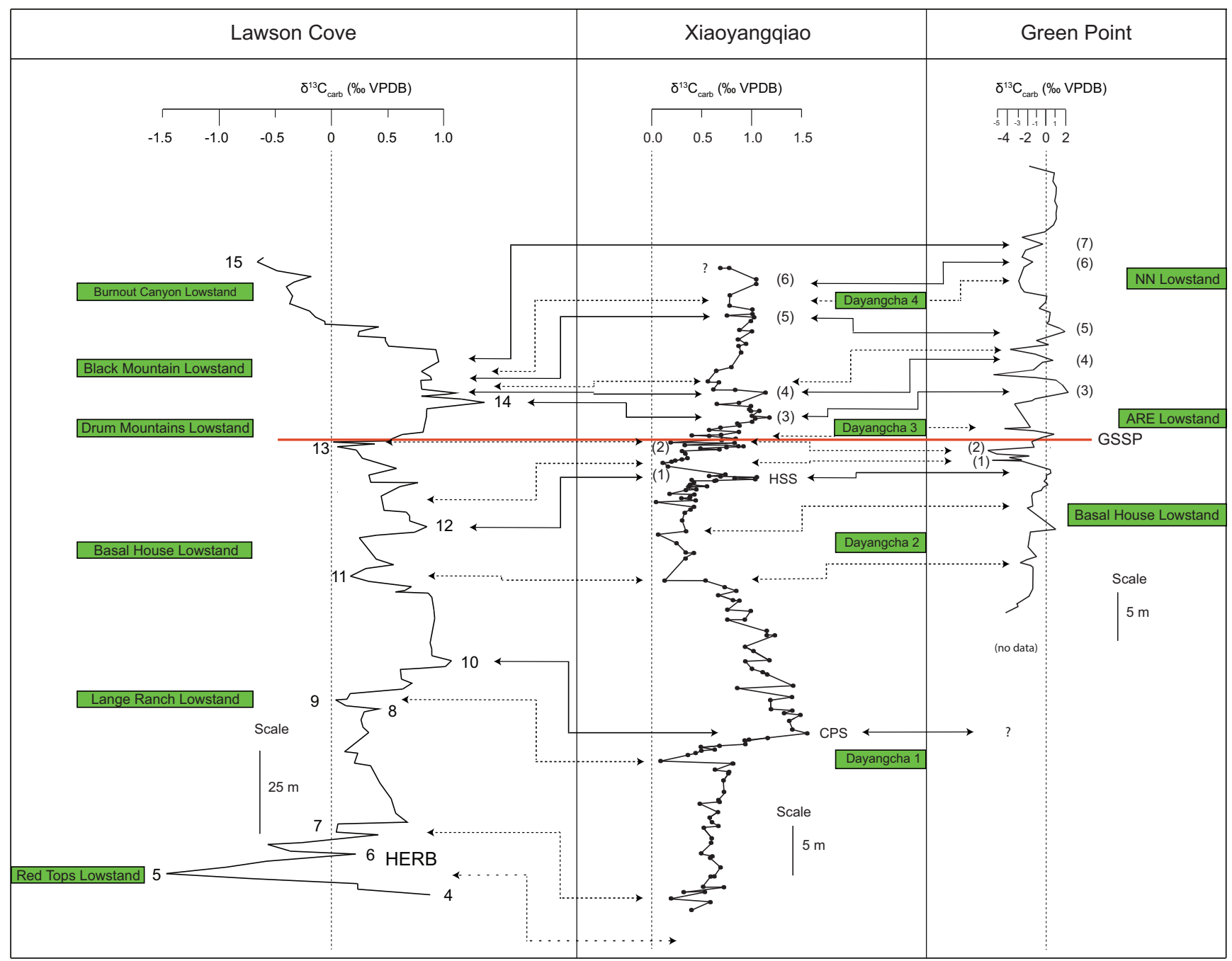

Figure 12. Interpreted match between the Lawson Cove ASSP section, Xiaoyangqiao ASSP section and the Green Point GSSP section. The C isotope profile from the Lawson Cove ASSP section, Utah, USA is based on Miller et al. (2015); the C isotope curves from Xiaoyangqiao ASSP section and Green Point GSSP section are from Stouge et al. (2017) and Wang et al. (2019). 
graphically well constrained.

A following prominent negative-positive swing in the Lawson Cove ASSP section is from very low positive peak 11 to the high positive peak 12, at ca. $120 \mathrm{~m}$, and is from within the Hirsutodontus simplex Subzone of the Cordylodus intermedius Zone. This isotope curve pattern is similar to that displayed in the Xiaoyangqiao ASSP section, in which the HSS peak from the upper C. caboti Zone is here considered to be a match to the positive peak 12 in the H. simplex Subzone of the Lawson Cove ASSP section (Fig. 12).

The following upsection strong negative swing, almost reaching the baseline, of peak 13 from within the upper Clavohamulus hintzei Subzone is a match to the pattern seen in the Xiaoyangqiao ASSP section, shown by the negative excursion 2. In the Lawson Cove ASSP section and upsection from peak 13, there is a prominent rise towards the maximum peak 14, which is immediately below the base of the Iapetognathus Zone (Miller et al., 2015). Peak 14 represents the maximum peak in the Lawson Cove ASSP section. However, it is not a clear match, because there are two rather than one large positive peak in the positive excursion of the Xiaoyangqiao ASSP section (i.e., 3 and 4 on Fig. 6; Wang et al., 2019). Peak 14 lies in the uppermost $C$. lindstromi Zone in the Lawson Cove ASSP section and the large spike 4 of the Xiaoyangqiao ASSP section may correspond to a smaller peak in the Lawson Cove ASSP section as marked on Fig. 12. The positive peak at $175 \mathrm{~m}$ in the Lawson Cove ASSP section is not seen in the Xiaoyangqiao ASSP section. It is marked by the presence of $C$. angulatus, which represents a level higher level than the investigated interval in the Xiaoyangqiao ASSP section.

\section{Sea Level}

The Dayangcha 1 lowstand of the Xiaoyangxiao ASSP section, which is recorded at the base of the Cordylodus proavus Zone, is coeval to the eustatic Lange Ranch lowstand of the Lawson section (Fig. 12). The Dayangcha 2 lowstand at the top of the Cordylodus caboti - basal Cordylodus intermedius zones corresponds to the Basal House lowstand, and the Dayangcha 3 lowstand at the Cordylodus intermedius basal C. lindstromi zones corresponds to the Drum Mountains lowstand of the Lawson Cove ASSP section. The same lowstand is recognized at unit 24 in the Green Point GSSP section and there it is named the ARE lowstand (Fig. 12; cf., Cooper, 1999; Cooper et al., 2001; Wang et al., 2019). The Dayangcha 4 lowstand in the Xiaoyangqiao ASSP section corresponds to the Black Mountain lowstand in the Lawson Cove ASSP section and to the NN lowstand of the Green Point GSSP section (Fig. 12).

\section{Summary of Correlation}

The correlation and match of the Xiaoyangqiao ASSP section to the Green Point GSSP section (Cooper et al., 2001; Wang et al., 2019), the Lawson Cove ASSP section (Miller et al., 2015, 2019) and the Wa'ergang Section, Hunan, South China (Dong and Zhang, 2017) is shown in Fig. 13.

This correlation spans a shallow water depositional setting (inner platform; Lawson Cove), a deeper water depositional setting (outer shelf to shelf margin; Xiaoyangqiao ASSP section), a deep-water setting (lower slope; Green Point GSSP section) and a lower slope-basinal deposition (Wa'ergang section). The Xiaoyangqiao ASSP section is the key section for the intercontinental correlation between shallow water shelly facies (Lawson Cove ASSP section), the deep-water lower slope graptolite facies (Green Point GSSP section) and the deepest water lower slope to basinal facies (Wa'ergang section). The Xiaoyangqiao ASSP section thus solves the longstanding problem in correlating the Cambrian-Ordovician boundary from shallow water facies with shelly fossils to deep water facies with graptolites (Fig. 13).

\section{Primary and Auxiliary markers for the Cam- brian-Ordovician boundary}

Since Chen et al. $(1985,1988)$ and Zhang et al. (1996) described the Xiaoyangqiao section in detail much additional biostratigraphic information has accumulated. Wang et al. (2019) reinvestigated and updated the fossil faunas and provided new carbon and other isotopes data and incorporated magnetostratigraphic data. The recognized markers/proxies (Wang et al., 2019) provide means of correlating/matching the ASSP to marine successions in other faunal provinces that lacking conodonts and/or graptolites. Trilobites and acritarchs provide only broad characterization of the ASSP level and are not at this stage proposed as proxies. Features in the magneto- and chemostratigraphic records provide non-biostratigraphic proxies:

(1) the Eoconodontus notchpeakensis and Cordylodus primitivus Bagnoli et al., 1987 association. This is the start of the significant Cordylodus evolutionary lineage, the members of which are used as global markers;

(2) the first appearance of Cordylodus proavus. Cordylodus proavus is cosmopolitan in marine settings and widely distributed in both Midcontinent and North Atlantic realms;

(3) the first appearance of Cordylodus caboti. The species is cosmopolitan in marine settings beyond the inner shelf in all biogeographic realms;

(4) the first appearance of Cordylodus intermedius. This species is cosmopolitan in marine settings at middle shelf and greater depths with occurrences in all biogeographic realms;

(5) the first appearance of Cordylodus lindstromi. The species is cosmopolitan and widely distributed in marine settings. It is a close proxy for the FAD of planktonic graptolites;

(6) the appearance of Iapetognathus preaengensis. The species is the first representative of the Iapetognathus evolutionary lineage (Stouge et al., 2020). At present the species is not well known, but probably is widely distributed as it is recorded also from Baltica;

(7) the first appearance of Iapetognathus jilinensis. This characteristic species is an early member of the Iapetognathus evolutionary lineage. The currently known distribution of Iapetognathus jilinensis is a deep-water palaeo-subtropical site in the Wa'ergang section, South China. It has been questionably identified in the Green Point GSSP section. Despite being rare, it is useful as a proxy for the appearance of planktonic graptolites;

(8) the first appearance of Rhabdinopora proparabola at $+20.9 \mathrm{~m}$. Although it is rarely found, and thus not widely spread, it is significant, because it represents the first planktonic graptolite and marks the lowermost Ordovician; 


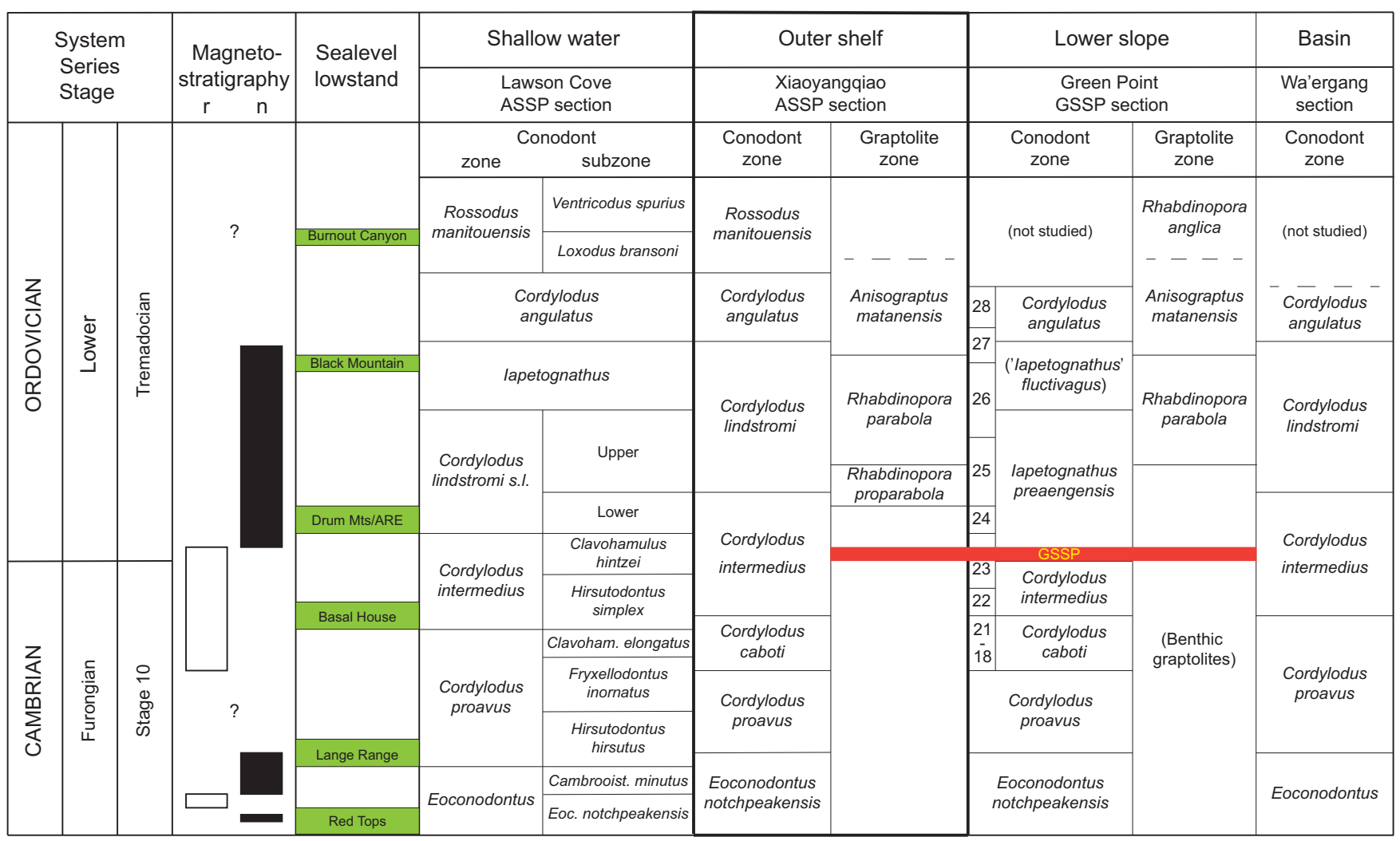

Figure 13. Synthesis of upper Cambrian to Lower Ordovician chronostratigraphy, lithostratigraphy, conodont biostratigraphy, sea-level lowstand and magnetostratigraphy events. The correlation between the Lawson Cove ASSP section, USA, (Miller et al., 2015), the Xiaoyangqiao ASSP section, North China (Wang et al., 2019), the Green Point GSSP section, western Newfoundland, Canada (Cooper et al., 2001; Stouge et al., 2017; Wang et al., 2019) and the Wa'ergang section, Hunan, South China (Dong and Zhang, 2017). The green boxes in the column with the Lawson Cove ASSP section represent lowstands (and gaps) and sequence boundaries (adopted from Miller et al., 2015 with references). The red line in the column with the Green Point GSSP section marks the position of the GSSP horizon in unit 23 (the numbers in the column for the Green Point GSSP section are the lithological units of James and Stevens, 1986). The Cordylodus angulatus and Rossodus manitouensis conodont zones in the Column 'Outer shelf' are from sections in the area (Chen, 1986; Yan et al., 2019).

(9) the first appearance of Rhabdinopora parabola. This species is well represented in the section; it has a worldwide distribution and is a key taxon for global correlation in deep-water settings;

(10) the first appearance of the planktonic graptolite Anisograptus matanensis;

(11) the maximum values of the positive excursion of $\delta^{13} \mathrm{C}_{\text {carb }}$ at ca. $+0.6 \mathrm{~m}$ (CPS). This is a global phenomenon and marks precisely the basal part of the Cambrian Cordylodus proavus conodont Zone;

(12) the positive spike (HSS) at $+17.4 \mathrm{~m}$. The excursion from high negative values to the high positive values is significant as it is a global signal;

(13) the minimum $\mathrm{C}$ isotope peak 2 at $+19.6 \mathrm{~m}$. It lies immediately below the GSSP horizon;

(14) the maximum peak (no. 3) of the positive excursion of $\delta^{13} \mathrm{C}_{\text {carb }}$ at $+21.4 \mathrm{~m}$. This peak is a global phenomenon. The interval may be represented by two or more high positive peaks in the deep-water settings; the Cambrian-Ordovician boundary horizon lies in the middle of the transition from low negative (no. 2) to positive values as it is fixed in the Green Point GSSP section;

(15) possibly the REE anomaly at ca. $+18.2 \mathrm{~m}$. A corresponding REE anomaly is also recorded in the Green Point GSSP section;

(16) the Cambrian-Ordovician boundary lies above the Basal House lowstand and beneath the Drum /ARE lowstand.

\section{Summary}

A GSSP section is never completely perfect and the introduction of the ASSPs provides a means for precise intercontinental correlation with the global GSSP. Wang et al. (2019) placed the level that corresponds to the GSSP horizon fixed in the Green Point GSSP section at $+19.9 \mathrm{~m}(0.2 \mathrm{~m})$ in the Xiaoyangqiao ASSP section. This horizon lies within the upper Cordylodus intermedius conodont Zone and one meter below the FAD of the first planktonic graptolites and $1.5 \mathrm{~m}$ below the base of the Cordylodus lindstromi Zone (Wang et al., 2019). It is closely associated with the shift from prominent negative values towards the positive values of the $\delta^{13} \mathrm{C}_{\text {carb }}$ profile.

Several biotic and non-biotic proxies can help in identifying the Cambrian-Ordovician horizon, as it is fixed in the Green GSSP Point GSSP section, western Newfoundland, Canada; most of these proxies have been identified in the Xiaoyangqiao ASSP section, the Lawson Cove ASSP section and the Green Point GSSP section.

The succession of the Dayangcha beds in the Xiaoyangqiao ASSP section Dayangcha, Jilin Province, North China, provides means for 

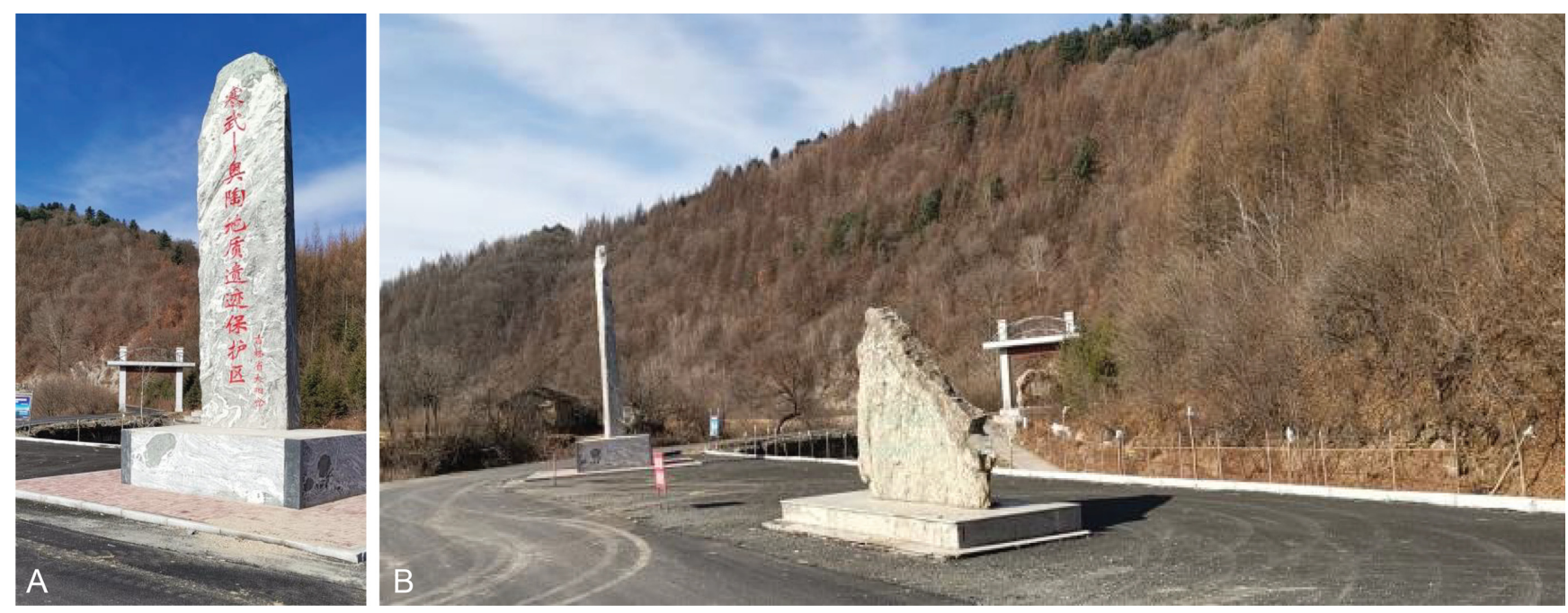

Figure 14. (A) The monument next to the Xiaoyangqiao ASSP section in the Cambrian-Ordovician protection zone. (B) Overview of the monument site. The Jiangyuan District Government erected the monument.

more precise recognition of the GSSP horizon. The section is geographically, and was palaeogeographically, remote from the Green Point GSSP section. In comparison with coeval successions from North America, Europe and Asia, the continuous Cambrian-Ordovician limestone-shale Dayangcha beds at the Xiaoyangqiao ASSP section in North China offer the possibility to document the Cambrian-Ordovician transition over a wide area and on a global scale, because it comprises a complete conodont, graptolite, acritarch and trilobite succession. Moreover, the $\delta^{13} \mathrm{C}_{\text {carb }}$-isotope data, sea-level proxies, magnetostratigraphic information and sequence stratigraphy provide additional and important results, enabling precise comparison with the Green Point GSSP section and other key and widespread sections in the world.

\section{Provisions for conservation, protection, and accessibility}

The Xiaoyangqiao ASSP section (Figs. 1, 2) is located on public land, and is easily accessible. It is relatively close (less than $25 \mathrm{~km}$ northeast) to Baishan City, which is the main urban settlement of the region and $1.5 \mathrm{~km}$ to northeast of Dayangcha town. The Government of Baishan City and the Jiangyuan district and their bureaus of natural resources recognize the significance of the Xiaoyangqiao section, and it has been included in the Cambrian-Ordovician protection zone since 1988 (Fig. 14). Any building, landscaping or other activities related to landscape alteration or destruction are strictly prohibited, whereas access to the area for research purposes is unrestricted.

\section{Acknowledgements}

We are grateful to the China Ministry of Sciences and Technology and the China Geological Survey for their financial support to the research project (No: 2015FY310100-7; No: DD20160120-04; DD20190009). We also gratefully appreciate support to the research project by the Chinese Commission of Stratigraphy and the Wuhan Center of Chinese Geological
Survey (WCCGS). Early conodont studies made by Gabriella Bagnoli and Yu-Ping Qi, was supported by the National Natural Science Foundation of China (Grant No. 41630101) for Yu-Ping Qi and the CAS President's International Fellowship Initiative (PIFI) grant (No. 2019VCA0005) for Gabriella Bagnoli. The fieldwork of Jörg Maletz was supported by Grant MA 1269/7-1 of Deutsche Forschungsgemeinschaft (DFG). Svend Stouge acknowledges financial support from the Carlsberg Foundation, Copenhagen, Denmark. We are very grateful to the two anonymous reviewers for their constructive reviews.

\section{References}

Adrain, J.M., and Westrop, S.R., 2006, New earliest Ordovician trilobite genus Millardicurus: the oldest known hystricurid. Journal of Paleontology, v. 80, pp. 650-671.

Azmy, K., Stouge, S., Brand, U., Bagnoli, G., and Ripperdan, R., 2014, High-resolution chemostratigraphy of the Cambrian-Ordovician GSSP: Enchanced global correlation tool. Palaeogeography, Palaeoclimatology, Palaeoecology, v. 409, pp. 135-144.

Bagnoli, G., Barnes, C.R., and Stevens, R.K., 1987, Lower Ordovician (Tremadocian) conodonts from Broom Point and Green Point, Western Newfoundland. Bollettino della Società Paleontologica Italiana, v. 25 , pp. $145-158$.

Barnes, C.R., 1988, The proposed Cambrian-Ordovician Global Boundary Stratotype and Point (GSSP) in Western Newfoundland, Canada. Geological Magazine, v. 125, pp. 381-414.

Bruton, D.L., Erdtmann, B.-D., and Koch, L., 1982, The Naersnes section, Oslo Region, Norway: a candidate for the Cambrian-Ordovician boundary stratotype at the base of the Tremadoc Series. In: Bassett, M.G., and Dean, M.G. (Eds.), The Cambrian-Ordovician Boundary: Sections, Fossil Distributions, and Correlations. Cardiff. National Museum of Wales, Geological Series, 3, pp. 61-69.

Bruton, D.L., Koch, L., and Repetski, J.E. 1988, The Nærsnes section, Oslo Region, Norway: Trilobite, graptolite and conodont fossils reviewed. Geological Magazine, v. 125, pp. 451-455.

Bulman, O.M.B., 1927, A monograph of British dendroid graptolites. Palaeontographical Society Monograph, pp. 1-28.

Bulman, O.M.B., 1954, The graptolite fauna of the Dictyonema shales of the Oslo region. Norsk Geologisk Tidsskrift, v. 33, pp. 1-40. 
Chen, J.Y. (Ed.), 1986, Aspects of the Cambrian-Ordovician Boundary in Dayangcha, China. China Prospect Publishing House, Beijing, 410 p.

Chen, J.Y., and Gong, W.L., 1986, Conodonts. In: Chen, J.Y. (Ed.), Aspects of the Cambrian-Ordovician Boundary in Dayangcha, China. China Prospect Publishing House, Beijing, pp. 93-223.

Chen, J.Y., Wang, Y.X., and Yang, J.D., 1986, Rare Earth and other trace elements in biogenic apatite across the Cambrian-Ordovician boundary. In: Chen, J.Y. (Ed.), Aspects of the Cambrian-Ordovician Boundary in Dayangcha, China. China Prospect Publishing House, Beijing, pp. 61-71.

Chen, J.Y., Teichert, C., Zhou, Z., Lin, Y., Wang, Z., and Xu, J., 1983, Faunal sequence across the Cambrian-Ordovician Boundary in northern China and its international correlation. Geologica et Palaeontologica, v. 17, pp. 1-15.

Chen, J.Y., Qian, Y.Y., Lin, Y.K., Zhang, J.M., Wang, Z.H., Yin, L.M., and Erdtmann, B.-D. (Eds.), 1985, Study on Cambrian-Ordovician Boundary Strata and Its Biota in Dayangcha, Hunjiang, Jilin, China. China Prospect Publishing House, Beijing, 139 p.

Chen, J.Y., Qian, Y.Y., Zhang, J.M., Lin, Y.K., Yin, L.M., Wang, Z.H., Wang, Z.Z., Yang, J.D., and Wang, Y.X., 1988, The recommended CambrianOrdovician boundary stratotype of the Xiaoyangqiao section (Dayangcha, Jilin Province), China. Geological Magazine, v. 125, pp. 415-444.

Chen, J.Y., Zhang, J.M., Nicoll, R.S., and Nowlan, G.S., 1995, Carbon and oxygen isotopes in carbonate rocks within Cambrian-Ordovician boundary interval at Dayangcha, China. Acta Palaeontologica Sinica, v. 34, pp. 393-409.

Cho, M., Lee, Y., Kim, T., Cheong, W., Kim, Y., and Lee, S.R., 2017, Tectonic evolution of Precambrian basement massifs and an adjoining fold-and-thrust belt (Gyeonggi Marginal Belt), Korea: An overview. Geosciences Journal, v. 21, pp. 845-865.

Cooper, R.A., 1999, Ecostratigraphy, zonation and global correlation of earliest Ordovician planktic graptolites. Lethaia, v. 32, pp. 1-14.

Cooper, R.A., Maletz, J., Wang, H., and Erdtmann, B.-D., 1998, Taxonomy and evolution of earliest Ordovician graptoloids. Norsk Geologisk Tidsskrift, v. 78, pp. 3-32.

Cooper R.A., Nowlan, G.S., and Williams, S.H., 2001, Global Stratotype Section and Point for base of the Ordovician System. Episodes, v. 24, pp. 19-28.

Dong, X.P., and Zhang, H., 2017, Middle Cambrian through lowermost Ordovician conodonts from Hunan, South China. Journal of Paleontology, Memoir, 73, pp. 1-89.

Druce, E.C., and Jones, P.J., 1971, Cambro-Ordovician conodonts from the Burke River Structural Belt, Queensland. Bureau of Mineral Resources, Australia, Bulletin, 110, pp. 1-159.

Dubinina, S.V., 2000, Konodonty i zonal'naya stratigrafiya pogranichnykh otlozhenii kembriya i ordovika [Conodonts and zonal stratigraphy of the boundary interval of the Cambrian and Ordovician]. Transactions of the Russian Academy of Sciences, Geological Institute, 517, 239 p. (in Russian).

Eichwald, E.J., 1840, Ueber das silurische Schichtensystem in Esthland. St. Petersburg, 210 p.

Eichwald, E.J., 1855, Beitrag zur geographischen Verbreitung der fossilen Thiere Russlands. Alte Periode. Bulletin de la Société Imperiale des Naturalistes de Moscou, v. 28, pp. 433-466.

Embry, A., and Johannessen, E., 1992, T-R sequence stratigraphy, facies analysis and reservoir distribution in the uppermost Triassic and Lower Jurassic succession, western Sverdrup Basin, Arctic Canada. In: Vorren, T.O., Bergsager, E., Dahl-Stamnes, .A., Holter, E., Johansen, B., Lie, E., Lund, T.B. (Eds.), Artic Geology and Petroleum Potential. Norvegian Petroleum Society, Special Publication, 2, pp. 121-146.

Emmons, E. 1855, American Geology: containing a statement of the principles of the science, with full illustrations of the characteristic American fossils, also an atlas and a geological map of the United States. Part II. J. Munsell, Albany, NY, 251 p.

Epstein, A.G., Epstein, J.P., and Harris, L., 1977, Conodont alteration - An index to organic metamorphism. United States Geological Survey Professional Paper, 995, $27 \mathrm{p}$.

Erdtmann, B.-D., 1986, Review of lithofacies and graptolite-based biofacies of three critical Cambrian-Ordovician boundary stratotype sections. In: Chen, J.Y. (Ed.), Aspects of the Cambrian-Ordovician Boundary in Dayangcha, China. China Prospect Publishing House, Beijing, pp. 374-391.

Erdtmann, B.-D. 1988, The earliest Ordovician nematophorid graptolites: taxonomy and correlation. Geological Magazine, v. 125, pp. 327-348.

Fortey, R.A., Landing, E., and Skevington, D., 1982, Cambrian-Ordovician boundary sections in the Cow Head Group, western Newfoundland. In: Bassett, M.G., Dean, W.T. (Eds.), The Cambrian-Ordovician Boundary: Sections, Fossil Distributions, and Correlations. National Museum of Wales, Geological Series, 3, Cardiff, pp. 95-129.

Furnish, W.M., 1938, Conodonts from the Prairie du Chien beds of the upper Mississippi Valley. Journal of Paleontology, v. 12, pp. 318-340.

Grabau, A.W., 1922, Ordovician fossils from North China. Palaeontology Sinica, Series B, 1, pp. 1-127.

Hedberg, H.D., (Ed.), 1976, International Stratigraphic Guide. J. Wiley \& Sons, New York, 200 p.

Hintze, L. F., 1951, Lower Ordovician detailed stratigraphic sections for western Utah. Utah Geological and Mineralogical Survey, Bulletin, no. 39,99 p.

Hintze, L.F., 1953, Lower Ordovician trilobites from western Utah. Utah Geological and Mineralogical Survey, Bulletin, no. 48, 249 p.

James, N.P., and Stevens, P.K., 1986, Stratigraphy and correlation of the Cambro-Ordovician Cow Head Group, western Newfoundland. Geological Survey of Canada, Bulletin, no. 366, 143 p.

Kaljo, D., Borovko, N., Heinsalu, H., Khazanovich, K., Mens, K., Popov, L., Sergeyeva, S., Sobolevskaya, R., and Viira, V. 1986, The Cambrian-Ordovician boundary in the Baltic-Ladoga Clint area (North Estonia and Leningrad Region, USSR). Proceedings of the Academy of Sciences of the Estonian SSR, Gology, v. 35, pp. 97-108.

Kindle, C.H., and Whittington, H.B., 1958, Stratigraphy of the Cow Head region, western Newfoundland. Geological Society of America, Bulletin, v. 69, pp. 315-342.

Kobayashi, T., 1955, The Ordovician fossils from the McKay Group in British Columbia, Western Canada, with a note on the early Ordovician paleogeography. Journal of the Faculty of Science of the University of Tokyo, v. 9, pp. 335-493.

Kuo, H.C., Duan, J.E., and An, S.L., 1982, Cambrian-Ordovician boundary in the North China Platform with description of trilobites. Journal of Jiling University, Earth Science Edition, v. 3, pp. 9-28 (in Chinese, with English abstract).

Lapworth, C., 1898, An Intermediate Textbook of Geology. 13th edition. Edinburgh and London.

Lee, J.H., Chen, J.T., and Chough, S.K., 2012, Demise of an extensive biostromal microbialite in the Furongian (late Cambrian) Chaomidian Formation, Shandong Province, China. Geosciences Journal, v. 16, pp. 275-287.

Lee, D.C., Choh, S.J., Lee, D.J., Ree, J.H., Lee, J.H., and Lee, S.B., 2017, Where art thou "the great hiatus? - review of Late Ordovician to Devonian fossil-bearing strata in the Korean Peninsula and its tectonostratigraphic implications. Geosciences Journal, v. 21, pp. 913-931.

Lin, Y.K., 1985, Graptolites. In: Chen, J.Y., Qian, Y.Y, Lin, Y.K., Zhang, J.M., Wang, Z.H., Yin, L.M., and Erdtmann, B.-E., (Eds.), Study of Cambrian-Ordovician boundary strata and its biota in Dayangcha, Hunjiang, Jilin, China. China Prospect Publishing House, pp. 55-65.

Lin, Y.K., 1986, A new planktonic graptolite fauna. In: Chen, J.Y. (Ed.), Aspects of the Cambrian-Ordovician Boundary in Dayangcha, China. China Prospect Publishing House, Beijing, pp. 224-254.

Lindström, M., 1955, Conodonts from the lowermost Ordovician strata of south-centra Sweden. Geologiska Föreningens i Stockholm Förhandlingar, v. 76, pp. 517-604.

Lu, Y.H., 1984, Report on the Cambrian-Ordovician boundary work in 
China. In Nanjing Institute of Geology and Palaeontology, Academia Sinica (Ed.), Stratigraphy and palaeontology of systemic boundaries in China, Cambrian and Ordovician boundary (1). Anhui Science and Technology Publishing House, Hefei, China, pp. 1-8.

Lu, Y.H., and Lin, H.L., 1984, Late Cambrian and earliest Ordovician trilobites of Jiangshan-Changshan area, Zhejiang. In: Nanjing Institute of Geology and Palaeontology, Academia Sinica (Ed.), Stratigraphy and palaeontology of systematic boundaries in China, Cambrian and Ordovician boundary (1). Anhui Science and Technology Publishing House, Hefei, China. pp. 45-143.

Maletz, J., Wang, X.F., Wang, C.S., Stouge, S., and Yan, C.B., 2017, The earliest planktic graptolites: taxonomy and correlation. In: Wang, X.F., Stouge, S., Maletz, J., Wang, C.H., and Yan, C.B. (Eds.), Field Guide and Abstracts for the Dayangcha International Workshop on the Cambrian-Ordovician Boundary. Wuhan Center of China Geological Survey, 2017.9, pp. 64-66.

Meng, X., Ge, M., and Taylor, M.E., 1997, Sequence stratigraphy, sealevel changes and depositional systems in the Cambro-Ordovician of the North China carbonate platform. Sedimentary Geology, v. 114, pp. 189-222.

Meyerhoff, A.A., Kamen-Kaye, M., Chen, C., and Taner, I., 1991, Stratigraphy, Palaeogeography and Tectonics. Kluwer Academic Publishers, Dordrecht, $188 \mathrm{p}$.

Miller, J.F., 1969, Conodont Fauna of the Notch Peak Limestone (CambroOrdovician), House Range, Utah. Journal of Paleontology, v. 43, pp. 413-439.

Miller, J.F., 1980, Taxonomic revisions of some Upper Cambrian and Lower Ordovician conodonts with comments on their evolution. University of Kansas, Paleontological Contributions, v. 99, pp. 1-39.

Miller, J.M., 1988, Conodonts as biostratigraphic tools for redefinition and correlation of the Cambrian-Ordovician Boundary. Geological Magazine, v. 125, pp. 349-362.

Miller, J.F., 2016, The Auxiliary Boundary Stratigraphic Section and Point (ASSP) for the base of the Ordovician System at Lawson Cove, Ibex Area, Utah, USA. In: McIlroy, D. (Ed.), International Symposium on the Ediacaran-Cambrian Transition 2017, Abstract Volume, p. 76.

Miller, J.F., 2019, Study and use of Upper Cambrian to Lower Ordovician conodonts in central, southern, and western Laurentia, 1933-2018. Palaeobiodiversity and Palaeoenvironments. doi.org/10.1007/s12549019-00380-9

Miller, J.F., and Flokstra, B.R., 1999, Graphic correlation of important Cambrian-Ordovician boundary sections. Quo Vadis Ordovician - Short Papers of the Eigth International Symposium on the Ordovician System. Acta Universitatis Carolinae, Geologica, v. 43, pp. 81-84.

Miller, J.F., Taylor, M.E., Stitt, J.H., Ethington, R.L., Hintze, L.F., and Taylor, J.F., 1982, Potential Cambrian-Ordovician boundary stratotype sections in western United States. In: Bassett, M.G., and Dean, W.T., (Eds.), The Cambrian-Ordovician boundary: sections, fossil distribution, and correlations. National Museum of Wales Geological Series, 3, pp. 155-180.

Miller, J.F., Evans, K.R., Loch, J.D., Ethington, R.L., Stitt, J.H., Holmer, L., and Popov, L.E., 2003, Stratigraphy of the Sauk III Interval (Cambrian-Ordovivian) in the Ibex area, Western Millard County, Utah and Central Texas. Brigham Young University Geology Studies, v. 47, pp. 21-118.

Miller, J.F., Evans, K. R., and Dattilo, B.F., 2012, The Great American Carbonate Bank in the miogeocline of western central Utah: tectonic influences on sedimentation. In: Derby, J. R., Fritz, R., Longacre, S. A., Morgan,W., and Sternbach, C. (Eds.), The Great American Carbonate Bank: The Geology and Petroleum Potential of the Cambro-Ordovician Sauk Sequence of Laurentia. American Association of Petroleum Geologists Memoir, 98, pp. 769-854.

Miller, J.F., Repetski, J.E., Nicoll, R.S., Nowlan, G., and Ethington, R.L., 2014, The conodont Iapetognathus and its value for defining the base of the Ordovician System, GFF, v. 136, pp. 185-188.

Miller, J.F., Evans, K.R., Ethington, R.L., Freeman, R.L. Loch, J.D.,
Repetski, J.E., Ripperdan, R.L., and Taylor, J.F., 2015, Proposed Auxiliary Boundary Stratigraphic Section and Point (ASSP) for the base of the Ordovician System at Lawson Cove, Utah, USA. Stratigraphy, v. 12, pp. 219-236.

Müller, K.J., 1959, Kambrische conodonten. Zeitschrift der Deutsche Geologische Gesellschaft, v. 111, pp. 435-485.

Nicoll, R.S., 1991, Differentiation of Late Cambrian-Early Ordovician species of Cordylodus (Conodonta) with biapical basal cavities. BMR Journal of Australian Geology and Geophysics, v. 12, pp. 223-244.

Nicoll, R.S., Miller, J.F., Nowlan, G.S., Repetski, J.E., and Ethington, R.L., 1999, Iapetonudus (n. gen.) and Iapetognathus Landing, unusual earliest Ordovician multielement conodont taxa and their utility for biostratigraphy. Brigham Young University Geology Studies, v. 44, pp. 27-101.

Nowlan, G.S., and Nicoll, R.S., 1995, Re-examination of the conodont biostratigraphy at the Cambrian-Ordovician Xiaoyangqiao section, Dayangcha, Jilin Province, China. In: Cooper, J.D., Droser, M.L., and Finney, S.C. (Eds.), Ordovician Odyssey: Short Papers for the Seventh International Symposium on the Ordovician System. Pacific Section of Society for Sedimentary Geology (SEPM), Book 77, pp. 113-116.

Obut, A.T., and Sobolevskaja, R.F., 1962, Problemi neftegazonosti Sovjetskoj Arktiki: Paleontologija i biostratigrafija: Graptoliti rannego Ordovika na Taimyre. Trudy Nautshno Issledowatelskogo Instituta Geologii, arktiki 127, pp. 65-85.

Pander, C.H., 1856, Monographie der fossilen Fische des silurischen Systems der Russich-Baltischen Gouvernements. Akademie der Wissenschaften, St. Petersburg, 91 p.

Popov, L.E., Holmer, L.E., and Miller, J.F., 2002, Lingulate brachiopods from the Cambrian-Ordovician boundary beds of Utah. Journal of Paleontology, v. 76, 211-228.

Qian, Y.Y., 1986, Trilobites. In: Chen, J.Y. (Ed.), Aspects of the CambrianOrdovician Boundary in Dayangcha, China. China Prospect Publishing House, Beijing, pp. 255-306.

Remane, J., Bassett, M.G., Cowie, J.W., Gohrbandt, K.H., Lane, H.R., Michelsen, O., and Naiwen, W., 1996, Revised guidelines for the establishment of Global chronostratigraphic standards by the International Commission on Stratigraphy (ICS). Episodes, v. 19, pp. 77-81.

Peng, S.C., 1984, Cambrian-Ordovician boundary in the Cili-Taoyuan border area, northwestern Hunan with description of relative trilobites. In: Nanjing Institute of Geology and Palaeontology, Academia Sinica (Ed.), Stratigraphy and palaeontology of systemic boundaries in China, Cambrian and Ordovician boundary (1). Anhui Science and Technology Publishing House, Hefei, China, pp. 285-405.

Peng, S.C., 2009a, Review on the studies of Cambrian trilobite faunas from Jiangnan slope belt, South China, with notes on Cambrian correlations between South and North China. Acta Palaeontologica Sinica, v. 48, pp. 437-452.

Peng, S.C., 2009b, The newly-developed Cambrian biostratigraphic succession and chronostratigraphic scheme for South China. Chinese Science Bulletin, v. 54, pp. 4161-4170.

Peng, S.C., Babcock, L.E., and Cooper, R.A., 2012, The Cambrian Period. In: Gradstein, F.M., Ogg, G., Schmitz, M., and Ogg, G.J., (Eds.), The Geologic Time Scale 2012. Boston, Elsevier, pp. 451-502.

Pouille, L., Danelian, T., and Maletz, J., 2014, Radiolarian diversity changes during the Late Cambrian-Early Ordovician transition as recorded in the Cow Head Group of Newfoundland (Canada). Marine Micropaleontology, v. 110, pp. 25-41.

Ripperdan, R.L., and Kirschvink, J.L., 1992, Paleomagnetic results from the Cambrian-Ordovician boundary sections at Black Mountain, Georgina Basin, western Queensland, Australia. In: Webby, B.D., Laurie, J.R. (Eds.), Global Perspectives on Ordovician Geology. A.A. Balkema, Rotterdam, pp. 93-103.

Ripperdan, R.L., and Miller, J.F., 1995, Carbon isotope ratios from the Cambrian-Ordovician boundary section at Lawson Cove, Ibex area, Utah. In: Cooper, J.D., Droser, M.L., and Finney, S.C. (Eds.), Ordovician Odyssey: Short Papers for the Seventh International Symposium 
on the Ordovician System: Pacific Section SEPM, Fullerton, California, pp. 129-132.

Ripperdan, R.L., Magaritz, M., and Kirschvink, J.L., 1993, Carbon isotope and magnetic polarity evidence for non-depositional events within the Cambrian-Ordovician boundary section near Dayangcha, Jilin Province, China. Geological Magazine, v. 130, pp. 443-452.

Ripperdan, R.L., Magaritz, M., Nicoll, R.S., and Shergold, J.H., 1992, Simultaneous changes in carbon isotopes, sea level, and conodont biozones within the Cambrian-Ordovician boundary interval at Black Mountain, Australia. Geology, v. 20, pp. 1039-1042.

Ross, R.J., Jr., Hintze, L.F., Ethington, R.L., Miller, J.F., Taylor, M.E., Repetski, J.E., Sprinkle, J., and Guensburg, T.E., 1997, The Ibexian, lowermost series in the North American Ordovician. In: Taylor, M.E. (Ed.), Early Paleozoic Biochronology of the Great Basin,Western United States. U.S. Geological Survey Professional Paper, 1579, 50 p.

Ruedemann, R., 1937. A new North American graptolite faunule. American Journal of Science, v. 33, pp. 57-62.

Stouge, S., Bagnoli, G., and McIlroy, D., 2017, Cambrian-Middle Ordovician Platform-slope Stratigraphy, Palaeontology and Geochemistry of Western Newfoundland. Geological Survey of Newfoundland and Labrador, Open File, v. 012B/0692, 106 pp.

Stouge, S. Bagnoli, G., and Rasmussen, J.A., 2020, Late Cambrian (Furongian) to mid-Ordovician euconodont events on Baltica: Invasions and immigrations. Palaeogeograpphy, Palaeoclimatology, Palaeoecology v. 549, doi.org/10.1016/j.palaeo.2019.04.007

Terfelt, F., Bagnoli, G., and Stouge, S., 2012, Re-evaluation of the conodont Iapetognathus and implications for the base of the Ordovician System GSSP. Lethaia, v. 45, pp. 227-237.

Tripathy, G.R., Hannah, J.L., Stein, H.S., and Yang, G., 2014, Re-Os age and depositional environment for black shales from the CambrianOrdovician boundary, Green Point, western Newfoundland. Geochemistry, Geophysics, Geosystems, v. 15, pp. 1021-1037.

Viira, V., Sergeyeva, S., and Popov, L., 1987, Earliest representatives of the genus Cordylodus (Conodonta) from Cambro-Ordovician boundary beds of North Estonia and Leningrad Region. Proceedings of the Academy of Sciences of the Estonian SSR. Geology, v. 36, pp. 145-153.

Wang, H., Chu, X., Liu, B. Hou, H. and Ma, L. et al. 1985, English explanation of the 'Atlas of the Palaeogeography of China'. Pts I and II, 25 pp. Atlas of the Palaeogeography of China. Cartographic Publishing House, Beijing, China (in Chinese with English summary), 82 p, 143 plates, Appendix I, II.

Wang, X.F., Chen, X., Chen, X.H., and Zhu, Z.Y., 1996, Stratigraphical Lexicon of China - The Ordovician System. Geological Publishing House, Beijing, 192 p.

Wang, X.F., Stouge, S., Maletz, J., Wang, C.H. and Yan, C.B., 2017, Field Guide and Abstracts for the Dayangcha International Workshop on the Cambrian-Ordovician boundary. Wuhan Center of China Geological Survey. Open file report, 2017.9, $90 \mathrm{p}$.

Wang, X.F., Stouge, S., Maletz, J., Bagnoli, G., Qi, Y.P., Raevskaya, E., Wang, C.S., and Yan, C.B., 2019, Correlating the global CambrianOrdovician boundary: Precise comparison of the Xiaoyangqiao sec- tion, Dayangcha, North China with the Green Point GSSP sections, Newfoundland, Canada. Palaeoworld, v. 28, pp. 243-275.

Wang, Z.H., Zhen, Y.Y., Zhang, Y.D., and Wu, R.C., 2016, Review of the Ordovician conodont biostratigraphy in the different facies of North China. Journal of Stratigraphy, v. 46, pp. 1-16 (in Chinese, with English abstract).

Yan, C.B., Stouge, S., Wang X.F, and Wang C.S., 2019, Upper lower Tremadocian (Lower Ordovician) conodonts from the upper Yeli Formation of Dayancha, Jilin Province, North China. In: Obut, O.T., Sennikov, N.V., Kipriyanova, T.P. (Eds.), $13^{\text {th }}$ International symposium on the Ordovician System Novosibirsk, Russia, Contributions, pp. 235-238.

Yang, Y.D., Wang, Y.X., Tao, X.C., Li, H.M., and Wang, Z.Z., 1986, Rb-Sr dating on the Cambrian-Ordovician boundary interval. In: Chen, J.Y. (Ed.), Aspects of the Cambrian-Ordovician Boundary in Dayangcha, China. China Prospect Publishing House, Beijing, pp. 72-82.

Yin, L.M., 1985, Acritarchs. In: Chen, J.Y., Qian, Y.Y., Lin, Y.K., Zhang, J.M., Wang, Z.H., Yin, L.M., and Erdtmann, B.-D. (Eds.), Study on Cambrian-Ordovician Boundary Strata and Its Biota in Dayangcha, Hunjiang, Jilin, China. China Prospect Publishing House, Beijing, pp. 101-112.

Yin, L.M., 1986, Acritarchs. In: Chen, J.Y. (Ed.), Aspects of the Cambrian-Ordovician Boundary in Dayangcha, China. China Prospect Publishing House, Beijing, pp. 313-373.

Zhang, J.M., 1986, Description of sections. In: Chen, J.Y. (Ed.), Aspects of the Cambrian-Ordovician Boundary in Dayangcha, China. China Prospect Publishing House, Beijing, pp. 7-14.

Zhang, J.M., and Chen, J.Y., 1986, Lithofacies sequence. In: Chen, J.Y. (Ed.), Aspects of the Cambrian-Ordovician Boundary in Dayangcha, China. China Prospect Publishing House, Beijing, pp. 15-34.

Zhang, J.M., Wang, H.F., Li, G.X., and Chen, J.Y., 1996, Redescription of the Dayangcha section as a candidate for the Global Cambrian-Ordovician Boundary Stratotype, Jilin Province, China. Journal of Stratigraphy, v. 20, pp. 81-103 (in Chinese, with English abstract).

Zhang, W.T., 1962, Ordovician of China. Symposium on Stratigraphy of China. Science Press, Beijing, 62 p. (in Chinese).

Zhang, Y.D., and Erdtmann, B.D., 2004, Tremadocian (Ordovician) biostratigraphy and graptolites at Dayangcha (Baishan, Jilin, NE China). Paläontologische Zeitschrift, v. 78, pp. 323-354.

Zhen, Y.Y., Zhang, Y.D., Wang, Z.H., and Percival, I.G., 2016, Huaiyuan Epeirogeny - Shaping Ordovician stratigraphy and sedimentation on the North China Platform. Palaeogeography, Palaeoclimatology, Palaeoecology, v. 448, pp. 363-370.

Zheng, Y.F., Xiao, W.J., and Zhao, G.C., 2013, Introduction to tectonics of China. Gondwana Research, v. 23, pp. 1189-1206.

Zhou, Z.Y., Wang, Z.H., and Zhang, J.M., 1984, Cambrian-Ordovician boundary and the proposed candidates for stratotype in North and Northeastern China. In: Nanjing Institute of Geology and Palaeontology, Academia Sinica (Ed.), Cambrian-Ordovician Boundary (2). Anhui Science and Technology Publishing House, Hefei, 62 p. (in Chinese).

Zhu, R.X., Yang, J.H., and Wu, F.Y., 2012, Timing of destruction of the North China Craton. Lithos, v. 149, pp. 51-60. 


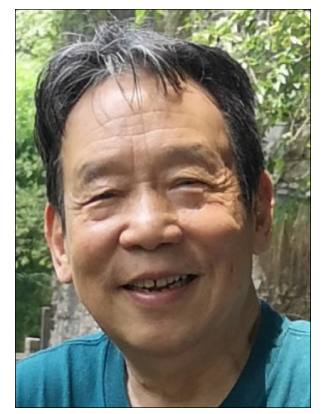

Xiaofeng Wang is professor of stratigraphy and paleontology at Wuhan Center of Geological Survey (WCGS) (Formel Yichang Institute of Geology and Mineral Resources) (YIGMR). He has been director of YIGMR and Vice Chairman of the Chinese Paleontology Association. Long-term engaged in the study of stratigraphy and paleontology, especially Ordovician and Silurian stratigraphy and graptolite and chitinozoans, but also involved with the research of the Triassic Guanling biota new discovered in Guizhou Province with marine reptile and crinoids.

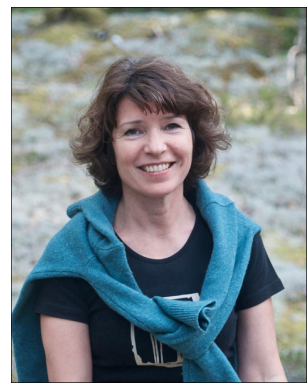

Elena G Raevskaya is a specialist in the field of Early Palaeozoic palynology mainly dealing with acritarch taxonomy, biostratigraphy and palaeobiogeography. She also experienced in Precambrian organic walled microfossils and was in charge of their systematic, biodiversity and evolution. She is currently the head of the department of Stratigraphy specialised in palynology, micropaleontology, stratigraphy and regional geology of Palaeozoic and Mesozoic oil- and gas-bearing basins of Russia, being also a Deputy Director of the JSC "Geologorazvedka" (Branch of Russian geological holding JSC "Rosgeo" in Saint-Petersburg, Russia) and Vice President of the Russian Paleontological Society. Her personal studies are related to Ordovician acritarchs from Baltica, Siberia and the high Arctic.

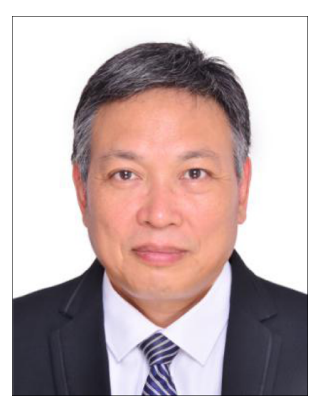

Chuanshang Wang is professor of stratigraphy and paleontology at Wuhan Center of China Geological Survey (WHCGS). He has been engaged in the graptolite, the Early Paleozoic stratigraphy and the shale gas investigation for the last decade. He is currently focused on the black shale, shale gas and the graptolite zonation and correlation of the OrdovicianSilurian transitional period in South China with his colleagues.

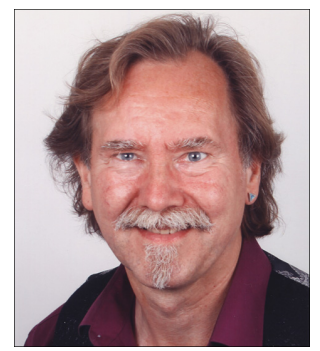

Jörg Maletz is a Palaeontologist at Freie Universität Berlin, Germany, working on Pterobranchia (Graptolites and their extant relatives) and on Palaeozoic Radiolaria. His research is mainly focused on evolution of the Palaeozoic Graptolithina and their biostratigraphical use. His recent publications includes a book on graptolites (Graptolite Paleobiology, Wiley Blackwell, 2017) and the co-ordination of the Treatise on Invertebrate Paleontology, Hemichordata (including Enteropneusta and Pterobranchia), which is nearly finished. He is currently working on Ordovician-Silurian successions of China, Scandinavia (Norway, Sweden) and eastern North America (Canada, Newfoundland) with a number of colleagues.

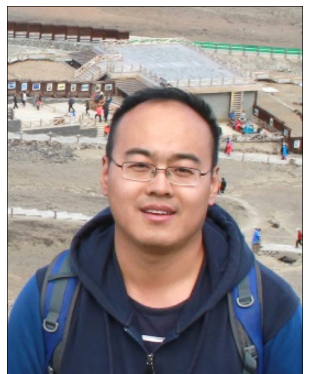

Chunbo Yan is Research Associate at Wuhan Center of China Geological Survey (WCGS) specializing in conodont biostratigraphy. His current research focuses on the CambrianOrdovician boundary and the conodont biostratigraphy of the Permian-Triassic transition in China, and the sedimentary environment of Nanzhang-Yuan'an fauna of the Early Triassic. 